\title{
A Conceptual Framework to Manage Resilience and Increase Sustainability in the Supply Chain
}

\author{
Antonio Zavala-Alcívar ${ }^{1, *(\mathbb{D}, \text { María-José Verdecho }}{ }^{2,3, * \mathbb{C} \text { and Juan-José Alfaro-Saiz }}{ }^{2,3}$ \\ 1 Faculty of Industrial Engineering, Universidad Laica Eloy Alfaro de Manabí, 130214 Manta, Ecuador \\ 2 Department of Business Organisation, Universitat Politècnica de València, Camino de Vera $\mathrm{S} / \mathrm{N}$, \\ 46022 Valencia, Spain; jalfaro@omp.upv.es \\ 3 Research Centre on Production Management and Engineering (CIGIP), Universitat Politècnica de València, \\ Camino de Vera S/N, 46022 Valencia, Spain \\ * Correspondence: antonio.zavala@uleam.edu.ec (A.Z.-A.); mverdecho@omp.upv.es (M.-J.V.)
}

Received: 14 June 2020; Accepted: 25 July 2020; Published: 5 August 2020

check for updates

\begin{abstract}
The challenges of global economies foster supply chains to have to increase their processes of collaboration and dependence between their nodes, generating an increase in the level of vulnerability to possible impacts and interruptions in their operations that may affect their sustainability. This has developed an emerging area of interest in supply chain management, considering resilience management as a strategic capability of companies, and causing an increase in this area of research. Additionally, supply chains should deal with the three dimensions of sustainability (economic, environmental, and social dimensions) by incorporating the three types of objectives in their strategy. Thus, there is a need to integrate both resilience and sustainability in supply chain management to increase competitiveness. In this paper, a systematic literature review is undertaken to analyze resilience management and its connection to increase supply chain sustainability. In the review, 232 articles published from 2000 to February 2020 in peer-reviewed journals in the Scopus and ScienceDirect databases are analyzed, classified, and synthesized. With the results, this paper develops a conceptual framework that integrates the fundamental elements for analyzing, measuring, and managing resilience to increase sustainability in the supply chain. Finally, conclusions, limitations, and future research lines are exposed.
\end{abstract}

Keywords: supply chain management; resilience; sustainability; performance management; conceptual framework; literature review

\section{Introduction}

The rapid advance of globalization makes it necessary for organizations to maintain a higher rate of business innovation, needing to support solid collaboration processes that, at the same time, cause dependency between organizations. This fact has increased the level of vulnerability as well as the consequences of a possible interruption in operations [1]. Organizations pursue having continuity in their operations after a disruptive event occurs [2,3]. Supply chain resilience (SCRES) is defined as "the ability to proactively plan and design the supply chain network for anticipating unexpected disruptive (negative) events, respond adaptively to disruptions while maintaining control over structure and function and transcending to a post-event robust state of operations, if possible, more favorable than the one prior to the event, thus gaining competitive advantage" [4] (p. 925).

On the other hand, sustainable supply chain management can be defined as "the management of material, information and capital flows, as well as cooperation among companies along the supply chain, while taking goals from all three dimensions of sustainable development, i.e., economic, environmental and social, into account, which are derived from customer and stakeholder requirements" [5]. All the 
companies that integrate the supply chain should engage in developing actions to achieve the goals of the three dimensions [6]. Then, a supply chain is moving towards sustainable supply chain management when it incorporates the three dimensions of sustainability in its strategy [7].

Analysis of the relationships between resilience and sustainability is supported in supply chain management [8]. Marchese et al. (2018) [9] state that the relationship between resilience and sustainability can take three different forms: Sustainability and resilience as separate conceptual objectives; sustainability as a component of resilience; or resilience as a component of sustainability. The first form states that managing sustainability does not contribute to resilience, nor does managing resilience to sustainability. Its application and results are exclusive. The second structure states that the ultimate goal of the system is resilience, and that sustainability is a process that helps this goal. The third-way analyses resilience as a necessary precondition for the fulfillment of sustainability, considering that business activities are sustainable as long as their core activities are resilient to disruptive events [9]. In this sense, if the system lacks resilience, it can only possess a fragile sustainability [10].

Considering the third type of relationships, if supply chains are to meet the dimensions of sustainability, their operational processes need to be resilient. This requires an analysis of the implications of implementing resilient strategies on sustainability dimensions. The type and extent of resilience management influences the performance of supply chains [11]. In many cases, supply chain management efforts do not explicitly link the aspects of resilience to the dimensions of sustainability [12], despite there being situations where resilient practices influence the sustainability of supply chains [13-15].

For example, increased risks of supply chain disruption require that the supply chain design and operations be flexible, redundant, and proactive, and that resources be reserved to deal with disruptions [16]. These network redundancies imply an increase in resource consumption and inventory use that affects a basic principle of sustainability, namely the efficient use of available resources in the supply chain [17-19]. Thus, the implementation of these resilient strategies mainly affects the economic and environmental dimensions of sustainability in an opposite sense.

Maintaining redundancy in the chain also implies having geographically dispersed suppliers and flexible supply policies [19-22] to ensure continuity of operations. These strategies affect the social dimension of sustainability because the supply chain would not contract exclusively with local suppliers. While it resists disruption, it should make its supply policy more flexible by contracting suppliers with lower sustainability performance but continuous supply [23].

There is also a positive relationship between resilient strategies and sustainability. The information systems' interoperability characterized by visibility and effective information exchange for joint decision making $[14,24]$ allows resilience to the disruptive events and adaptation to the new market structure. These strategies, although generating associated costs, generate a positive relationship, mainly with the social dimension of sustainability. The continuity of the supply chain operations generates employment in the locality, and the adaptability to the market requires actions that allow the supply chain to have a stronger link with the stakeholders to promote participation and support of the community [25].

Therefore, supply chains need to manage resilience by considering the dimensions of sustainability. They pursue to establish effective responses to eliminate the vulnerability and minimizing the impact of potential disruptions [15], while maintaining sustainable economic, social, and environmental dimensions of the supply chain $[13,14]$. Thus, the development of techniques and tools to support the configuration of supply chains and their operations requires conceptual frameworks and models that include all actors as well as the elements of resilience and sustainability dimensions [16].

Roostaie et al. (2019) [18] consider that proposing a single framework that integrates the principles of resilience with the dimensions of sustainability is a current line of research, given the complexity surrounding the differences between definitions, methodologies, and areas of applicability of resilience and sustainability, especially including the involvement of all stakeholders in the supply chain [18]. 
Failure to consider these guidelines may lead to implementation problems, resulting in poor supply chain performance and future conflicts [9].

A search of the previous academic literature on supply chain resilience management has been performed in three databases: Scopus, ScienceDirect, and Google Scholar. As a result, sixteen literature reviews on risk analysis and resilience management in supply chains were identified. These previous articles focus their research on defining resilience and describing the principles that integrate resilience $[4,24,26-34]$, strategies to recover from disruptive events $[1,30,33,35]$, and the qualitative and quantitative methods for measuring resilience [28,36-38]. Eight out of sixteen papers reviewed $[24,26,30-33,37,38]$ developed a conceptual framework for resilience management. The analysis of the previous literature is presented in Table A1 of the Appendix A, and it is structured by search horizon (range), number of papers analyzed, keywords, databases consulted, and whether the article presents a proposal of a conceptual framework. In addition, the table shows if the papers reviewed analyze the basic elements of the proposed conceptual framework. These elements are: Capabilities/principles/elements resilience (CPE); strategies to increase resilience (SR); risk (R); stakeholders of the supply chain (S); performance measurement (PM) if the paper just defined a set of performance indicators; performance measurement system (if the paper considers a structured performance framework); strategic level (SL); operational level (OL); sustainability dimensions (SUS); economic (ECO); social (SOC); environmental (ENV).

Thus, these analyzed conceptual frameworks overlook the integration of all relevant elements described above for managing resilience and enhancing sustainability into a single framework and how they are linked. First, the frameworks analyzed focus on establishing the internal linkage between capacities, principles, and elements of resilience in supply chains. Additionally, they identified strategies to increase resilience, but they have mainly been linked to the type of risk. Second, the frameworks do not integrate the effects of the type and level of risk and resilience strategies into the performance management system of the supply chain. Third, they do not conceptualize the performance management system at two levels, strategic and process levels, and establish the relationships between risk, resilience strategies, and operational processes and how the performance of operational processes impacts on strategic objectives. Fourth, the frameworks do not take into account all dimensions of sustainability. The main dimension analyzed is the economic one, but the social and environmental dimension and its linkage to resilience strategies and performance management are not discussed. Fifth, the impact of risks on stakeholders, and thus on operational and strategic supply chain objectives, is not analyzed. That is to say, these conceptual frameworks do not integrate the elements of resilience into a global framework that link: The strategy of the supply chain measured at strategic and process levels (including the sustainability dimensions), the nodes of the supply chain, the stakeholders involved, the risks that face the supply chain and the capabilities to develop to minimize the impact of these risks. To solve this gap, this paper performs a systematic literature review on resilience management and develops a conceptual framework that integrates the fundamental components for analyzing, measuring, and managing resilience to increase sustainability in the supply chain.

This paper is structured as follows. First, the research methodology is presented. Second, the analyses of the results are exposed. Third, a discussion of resilience conceptualization and sustainability is performed. Specifically, it presents a relational analysis of resilience and sustainability terms; the capabilities, principles, strategies, and elements of resilience; the supply chain risks; and the sustainability dimensions, sub-dimensions, and connection to resilience elements. Fourth, the conceptual framework for analyzing, measuring, and managing resilience to increase sustainability in the supply chain is presented. Finally, conclusions, limitations, and future research lines are exposed.

\section{Research Methodology}

The methodological approach applied, called the Systematic Literature Review (SLR) is proposed by Tranfield et al. (2003) and Denyer and Tranfield (2009) [39,40]. SLR consists of five phases: Research question formulation (phase 1), sourcing of relevant literature (phase 2), literature selection and 
evaluation (phase 3), analysis and synthesis (phase 4), and reporting and use of results (phase 5). Figure 1 shows the complete methodological process developed in the research.

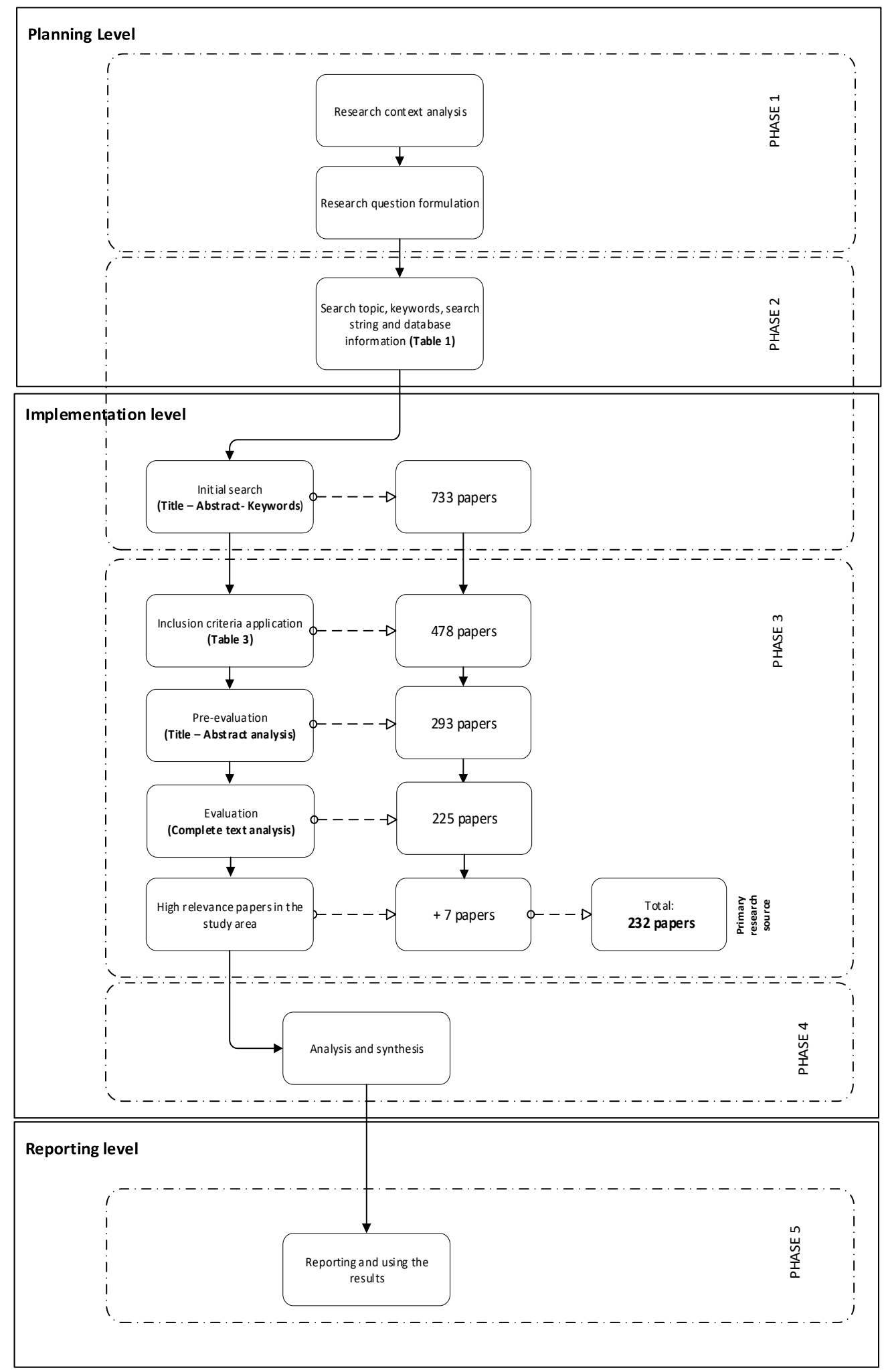

Figure 1. Methodological process developed in the research. Source: Adapted from Denyer and Tranfield (2009) [39]. 


\subsection{Phase 1: Research Question Formulation}

With the aim of developing a conceptual framework to enable the analysis, measurement, and management of resilience and sustainability among members of the supply chain, the following research question is set:

How can resilience management be integrated within a supply chain framework to increase sustainability?

This top-level research question is supported by the following sub-questions: How has supply chain resilience management evolved? What methods (quantitative and qualitative) are used to manage resilience in the supply chain? What nodes, processes, and stakeholders are involved? What terms are connected to resilience management? How is resilience conceptualized? What risks do supply chains face? What types of sustainability objectives are considered? How can strategy, sustainability dimensions, inter-organizational processes, and stakeholders be linked to resilience management to develop a conceptual framework for managing resilience to increase supply chain sustainability?

\subsection{Phase 2: Sourcing of Relevant Literature}

Four topics are considered in the search: "Management", "conceptual model", "resilience", and "supply chain". The search criteria are described in Table 1. The search covers the horizon from 2000 to February 2020.

Table 1. Search criteria.

\begin{tabular}{|c|c|c|c|}
\hline Search Topic & Keywords & Search Strings & Databases \\
\hline Supply chain & "supply chain" & (“supply chain" AND "resili *”) AND & \\
\hline Resilience & "resili*" & ("framework" OR "model") AND & Scopus, \\
\hline Framework & "framework", "model" & ("performance" OR "measur *" OR & ScienceDirect \\
\hline Management & $\begin{array}{l}\text { "performance", "measur *", "evaluat } \\
* ", \text { "management", "assessment" }\end{array}$ & $\begin{array}{c}\text { "evaluat *" OR “management" OR } \\
\text { "assessment") }\end{array}$ & \\
\hline
\end{tabular}

The asterisk $\left({ }^{*}\right)$ indicates the set of derived words starting with the referred prefix.

\subsection{Phase 3: Literature Selection and Evaluation}

The initial search was developed considering the title, abstract and keywords of the articles, obtaining 733 unduplicated papers in the Scopus and ScienceDirect databases. The inclusion criteria described in Table 2 were applied to the selection of papers. Thus, the search is limited to papers in peer-reviewed journals, both articles and literature reviews, in the search horizon from 2000 to February 2020 and in the English language. These criteria reduced the number of papers to 478.

Table 2. Inclusion criteria.

\begin{tabular}{cc}
\hline Inclusion Criteria & Description \\
\hline $\begin{array}{c}\text { Type of publication } \\
\text { Type of paper }\end{array}$ & $\begin{array}{c}\text { Published in peer-reviewed journals. Books, book chapters, and lectures were } \\
\text { excluded, unless they are of great importance for the topic of analysis. } \\
\text { Research articles and literature reviews } \\
\text { 2000-February 2020 } \\
\text { Publishing language }\end{array}$ \\
$\begin{array}{c}\text { English } \\
\text { Research context }\end{array}$ & $\begin{array}{c}\text { Papers that discuss how to assess and manage resilience at supply chain and/or } \\
\text { intra-organizational level }\end{array}$ \\
Relevance and citations & Additional articles relevant to the topic of intra-organizational resilience \\
\hline
\end{tabular}

Some results obtained may be irrelevant to the objective of the research, even if they meet the terms of the search string and the inclusion criteria. Therefore, a manual selection of the literature was developed by initially analyzing that the title and abstract respond to supply chain resilience management, resulting in 293 papers. Following this process, the full text of the papers was reviewed, and those analyzing the capabilities, principles, elements, or strategies of resilience in the supply chain were considered, resulting in 225 papers. Considering the citation reference analysis, 7 relevant articles 
analyzing intra-organizational resilience management were included, resulting in 232 papers available for further evaluation. The list of papers included in the systematic literature review are available as Supplementary Materials.

\subsection{Phase 4: Analysis and Synthesis}

Within this phase, 232 articles are analyzed by recording the characteristics and contributions of the papers according to the parameters established in Table 3.

The analysis of the articles was developed with the interpretation, integration, aggregation, and explanation approaches for the SLR methodology [41]. Due to the heterogeneous nature of the papers, the integration and aggregation approaches are highly relevant in this study because of the process of synthesizing multiple articles to answer the research questions.

Table 3. Parameters of research for papers analysis.

\begin{tabular}{|c|c|}
\hline Parameters & Aspect \\
\hline Descriptive analysis & Publication years, journals, industry, and geography analysis. \\
\hline Research methodology & Conceptual/theoretical, applied, analytical. Adapted from [42,43]. \\
\hline Node (physical view of the supply chain) & Supply chain participants who are considered for the management process. \\
\hline Processes & $\begin{array}{l}\text { The principal processes between the nodes of the supply chain, for example, } \\
\text { supply, manufacturing, logistics, retail, and so on. }\end{array}$ \\
\hline Stakeholders & $\begin{array}{l}\text { Stakeholders involved in the management process, e.g., } \\
\text { government/regulations, markets, customers, suppliers, shareholders, unions, } \\
\text { and others. }\end{array}$ \\
\hline Relational analysis & Analysis of the conceptual evolution of resilience in supply chains. \\
\hline $\begin{array}{c}\text { Capabilities, principles, strategies and } \\
\text { elements }\end{array}$ & $\begin{array}{l}\text { Capabilities, principles, and elements underlying resilience management, e.g., } \\
\text { flexibility, robustness, visibility, agility, velocity, change management, and so on. } \\
\text { Proactive, concurrent, and reactive strategies are analyzed. }\end{array}$ \\
\hline Supply chain risk & $\begin{array}{c}\text { Demand-side risk, supply-side risk, legal or bureaucratic risk, infrastructure } \\
\text { risk, and catastrophic or climate risk [44]. Probability and consequences are } \\
\text { analyzed as key factors of the disruptive event [45]. }\end{array}$ \\
\hline Sustainability dimensions & $\begin{array}{l}\text { Analysis of the principal types of criteria related to each sustainability } \\
\text { dimension (economic, social, and environmental dimensions). }\end{array}$ \\
\hline
\end{tabular}

\subsection{Phase 5: Reporting and Using the Results}

The relationships found between the articles and the research questions are presented. The objective is to apply the results in a global context for the generation of new knowledge on the analyzed topic [39].

\section{Results}

\subsection{Descriptive Analysis: Publication Years, Journals, Industry, and Geography Analysis}

Although the search horizon starts in 2000, and there are articles in the period 2000-2003 [1,31], the first article considered in this research was Christopher and Peck (2004) [46], where they proposed concepts and elements to build resilience in the supply chain. After this study, literature production remained low, and from 2013 onwards there is an increase. The years with the highest number of papers are after 2015, with a constant increase since 2017. Figure 2 shows the evolution of published papers since 2000.

There is a disparity of results in the principal publishing journals. Only $43.53 \%$ of the papers are published in journals with more than five papers, and the rest of the papers are published in 111 different journals. The different scopes and possible scenarios where resilience in supply chains is assessed generate this disparity. Table 4 shows the principal journals by the number of articles published and their percentages. 


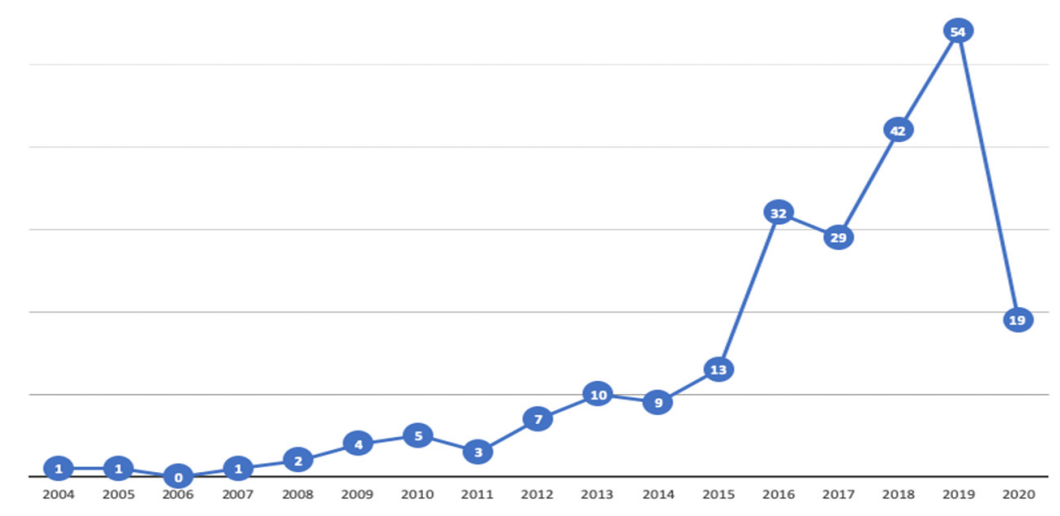

Figure 2. The trend of articles published by year (until February 2020).

Table 4. Principal journals. Number and percentage of articles published.

\begin{tabular}{ccc}
\hline Journal & No. Articles & $\mathbf{( \% )}$ \\
\hline International Journal of Production Economics & 17 & $7.33 \%$ \\
Supply Chain Management & 12 & $5.17 \%$ \\
International Journal of Production Research & 10 & $4.31 \%$ \\
Journal of Cleaner Production & 10 & $4.31 \%$ \\
Transportation Research Part E: Logistics and Transportation Review & 10 & $4.31 \%$ \\
Computers and Industrial Engineering & 9 & $3.88 \%$ \\
Sustainability & 8 & $3.45 \%$ \\
Annals of Operations Research & 5 & $2.16 \%$ \\
Benchmarking & 5 & $2.16 \%$ \\
IEEE Transactions on Engineering Management & 5 & $2.16 \%$ \\
Production Planning and Control & 5 & $2.16 \%$ \\
Others & 5 & $2.16 \%$ \\
\hline
\end{tabular}

Considering the research industry, 102 papers do not specify the industry. Within this category are papers with conceptual/theoretical methodology (28 papers) and papers that do not specify the sector of analysis (74 papers). The remaining 130 papers are distributed as follows: 40 papers focus on the automotive, mechanics, and electricity industry; 26 papers belong to transport, commerce, and logistics including land, sea, or air activity; 22 papers focus on the agri-food industry, where a high increase in published articles has been observed in the last five years; 14 papers belong to the mining and oil industry; 10 papers belong to the chemical-pharmaceutical industry and health services. The textile and construction industries appear with a lower percentage (Figure 3). In addition, in the last two years, the agri-food sector has generated the greatest number of papers, mainly focused on the importance of the continuity of activities in the supply chain after disruption.

The principal countries from which the authors come are: The United States with 67 papers (28.88\%), the United Kingdom with 33 papers (14.22\%), India with 30 papers (12.93\%), Iran with 24 papers (10.34\%), China with 23 papers (9.91\%), and Australia with 20 papers $(8.62 \%)$. 


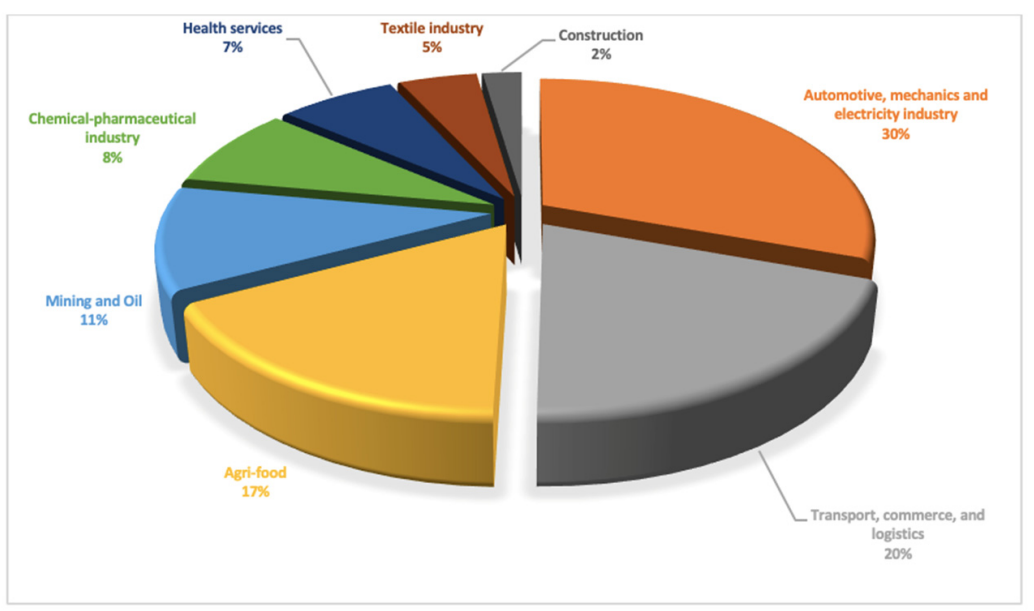

Figure 3. Analysis of the literature by industry.

\subsection{Descriptive Analysis by Research Methodology}

Natarajarathinam et al. (2009) classify articles in three types: (1) Conceptual/theoretical (provide a literature review or propose a new method, technique, or theoretical approach for managing resilience in supply chains); (2) applied (use techniques collecting data and observations and evaluating the information obtained); and (3) analytical (apply a mathematical or quantitative analytical model) [43]. Based on this division, the analytical methodology is the most widely used.

The most widely used methodology is analytical, so an analysis of the principal techniques used to manage resilience in the supply chain was generated (Table 5) based on the proposal used in Zimmer et al. (2016) [42].

Table 5. Principal analytical techniques used in the literature.

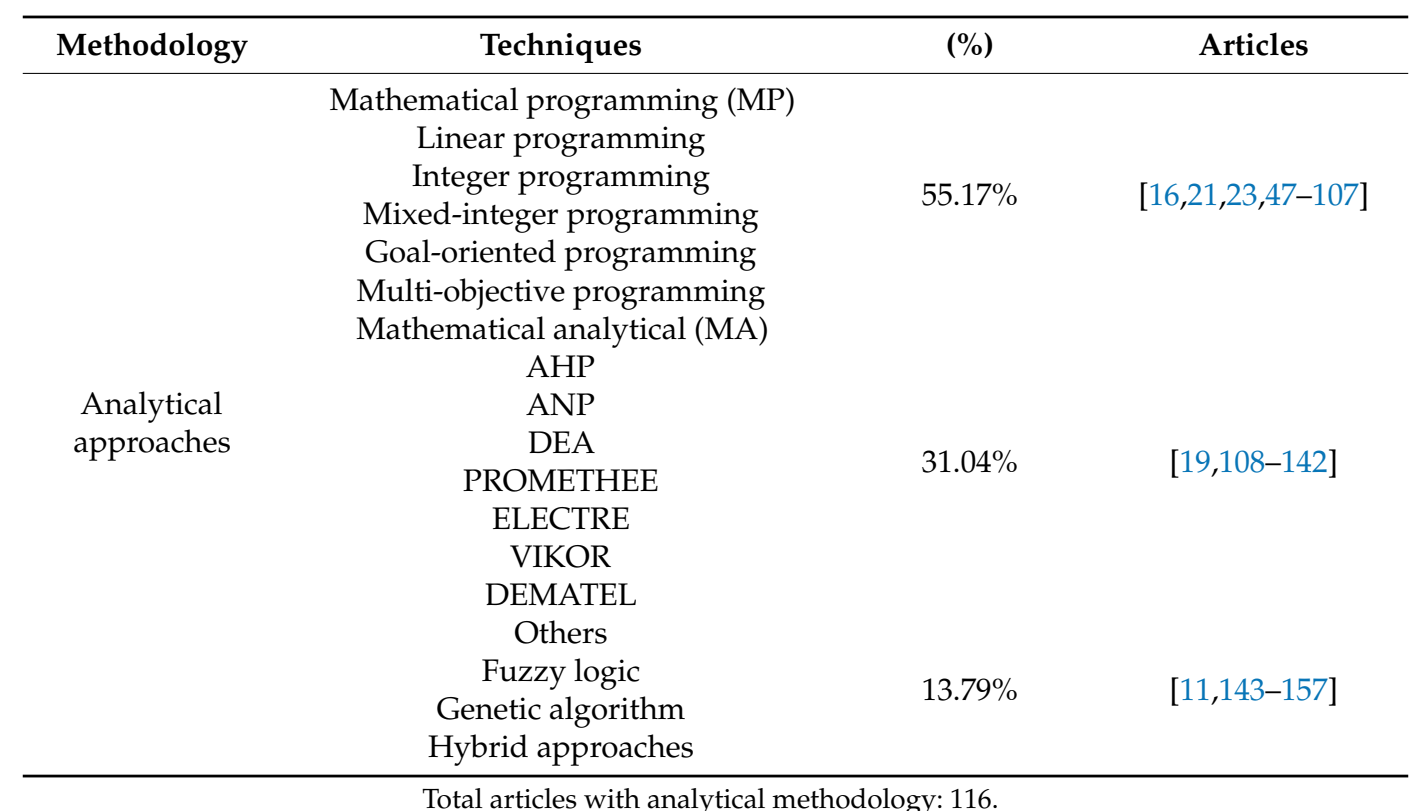

Table 6 shows the studies by industry and classifies them according to the methodology used. For example, mathematical programming is the most used in the automotive, mechanical, and electronic, agri-food, and chemical-pharmaceutical industries. The applied methodology is the most widely used in the transport, commerce, and logistics sector. 
Table 6. Relationship of industry and methodology.

\begin{tabular}{cccccc}
\hline Research Sector & $\begin{array}{c}\text { Conceptual/ } \\
\text { Theoretical }\end{array}$ & Applied & \multicolumn{3}{c}{ Analytical } \\
\cline { 3 - 6 } & & 7 & MP & MA & Others \\
\hline Automotive, mechanics, and electricity industry & & 11 & 10 & 3 & 7 \\
Transport, commerce, and logistics & 2 & 5 & 9 & 1 & 2 \\
Agri-food & 5 & 6 & 3 & 3 & 1 \\
Mining and oil & 1 & 2 & 6 & 1 & 1 \\
Chemical-pharmaceutical industry & & 3 & 3 & 2 & 1 \\
Health services & & 1 & 2 & 3 & \\
Textile industry & & 1 & & & \\
Construction & 2 & & & & \\
\hline
\end{tabular}

MP: Mathematical programming; MA: Mathematical analytical.

\subsection{Descriptive Analysis by Nodes, Processes, and Stakeholders Involved}

To achieve efficient supply chain resilience management, it is important to consider the type and extent of the supply chain $[33,158]$. Three papers have an intra-organizational scope, the remaining 229 papers, $62.45 \%$ of the papers (Figure 4), that consider the supply chain as their scope indicated that it is a complete chain, but they did not specify the number of nodes and in which nodes of the supply chain the management is performed. Additionally, $15.72 \%$ of the papers focus their resilience management on supplier-manufacturer; $7.86 \%$ of the papers relate to supplier-manufacturer-distributor (warehouse) nodes; and $4.37 \%$ of the papers focus on manufacturer-distributor (warehouse) nodes. Finally, $3.49 \%$ of the papers focus on manufacturer-distributor-retailer; $3.49 \%$ on distributor-retailer and $2.62 \%$ on a five-node supply chain from suppliers to customers.

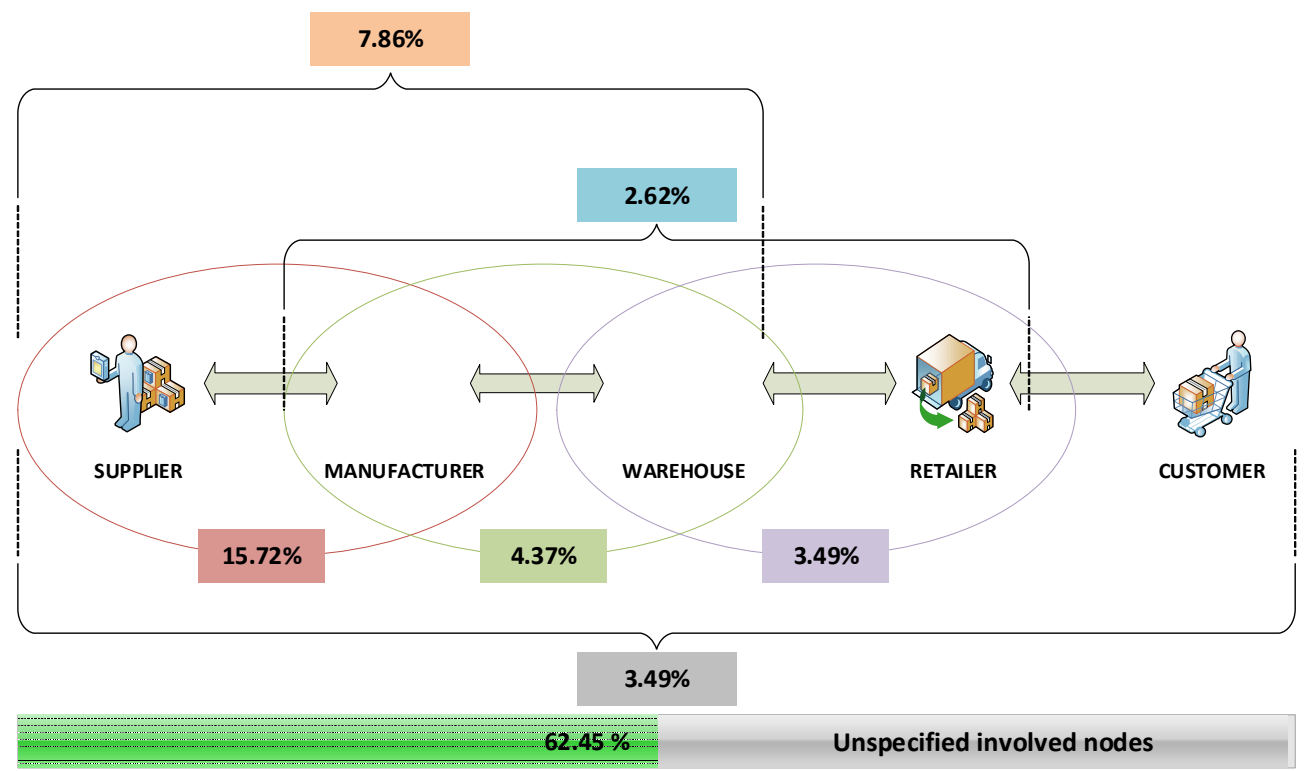

Figure 4. Supply chain nodes and percentage of papers $(n=229)$.

In a joint analysis with the principal industries, the supplier-manufacturer interface is where most research has been focused on. This happens in industries such as the automotive, mechanical, and electronic industry; transport, commerce, and logistics; agri-food; mining and oil; and the chemical and pharmaceutical industry.

For the analysis of the types of processes in a supply chain, the proposal of Chopra and Meindl (2013) [159] was adapted. One hundred and nine papers (54.23\%) do not specify the type of process considered. In other words, they indicate that it is a complete supply chain, but they do not specify the processes involved. For the rest of the 123 papers, the percentage of articles that analyze resilience by 
type of process is represented in Figure 5. For this percentage distribution, it is considered that an article can contemplate several processes in the supply chain.

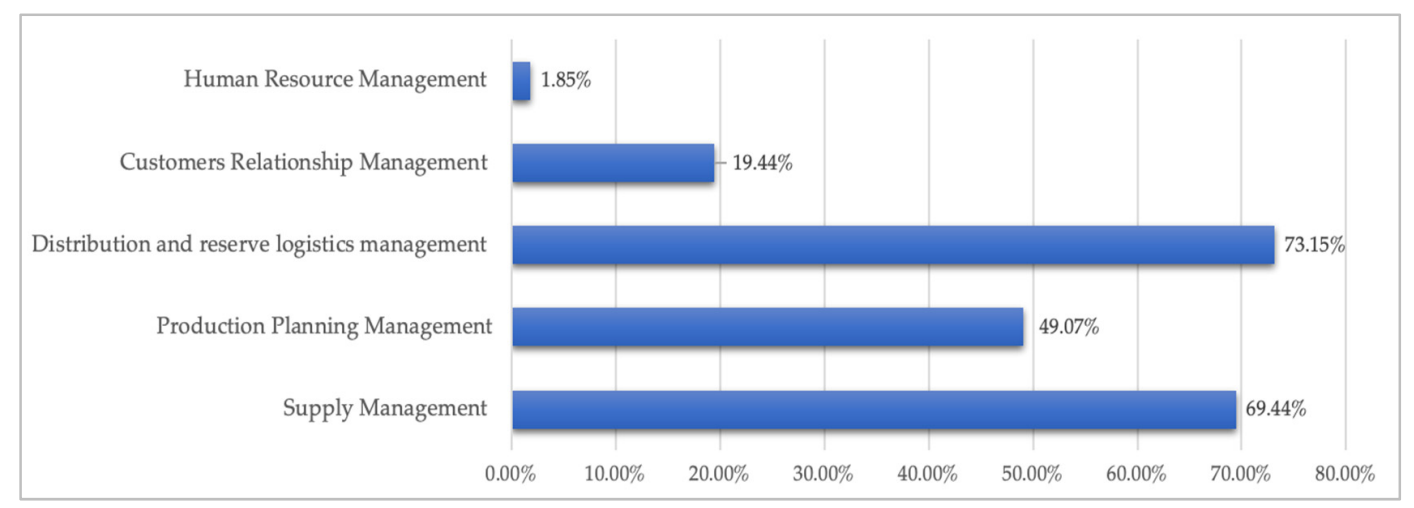

Figure 5. Process type analyzed in the literature $(n=123)$.

The processes with the greatest analysis are distribution and reverse logistics management (73.15\%), and supply management $(69.44 \%)$, given the importance of the continuity of the production process and adaptation to the market characteristics after a disruptive event.

Stakeholders in supply chain resilience management have also been analyzed. For this percentage distribution, it was considered that an item can include multiple stakeholders. Figure 6 represents the percentage amount of this analysis. Suppliers (192 papers) are the stakeholder group most often considered in resilience management because of their importance in the initiation and continuity of the production process. This analysis is consistent with that obtained in the node interface analysis (Figure 4) and process type analysis (Figure 5). The second group is the customers (175 papers). The third group is the shareholders (155 papers). The fourth group is competitors/market (154 papers), followed by government/legislations and NGOs (113 papers), and human resources/syndicates (16 papers).

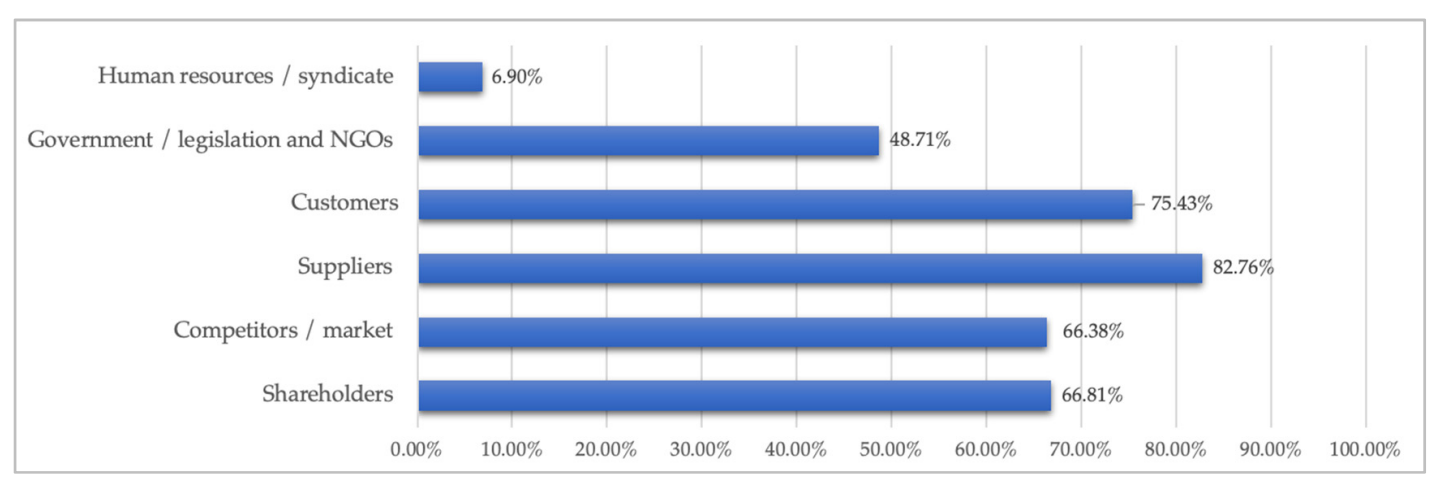

Figure 6. Stakeholders in supply chain resilience management.

\section{Discussion}

\subsection{Relational Analysis}

The term resilience is a multidimensional and multidisciplinary concept that comes from other research areas, mainly psychology and ecology [160], and has been adapted to intra-organizational business management and, subsequently, to the supply chain. Several articles propose a conceptualization of resilience based on different approaches within and outside the business environment $[2,4,27,30,31,33]$. 
The conceptual evolution of supply chain resilience management over time has broadened its scope. Early formalizations focused on reaction and recovery from disruptive events $[1,46,160,161]$. From there, adaptation, anticipation, and preparation were considered $[2,4,29,30,160]$, and recently, design for prevention and minimization of impact and cumulative learning and continuous improvement have been incorporated [33].

Using the VOSviewer software, a relational analysis of the keywords contained in the articles was developed. Figure 7 shows the conceptual evolution since 2014. In the last years, the keywords have been risk analysis, vulnerability, disruption, and disruptive events. In addition, the articles now focus on methodological aspects (stochastic models, optimization, surveys, etc.), sustainability, and supply chain performance.

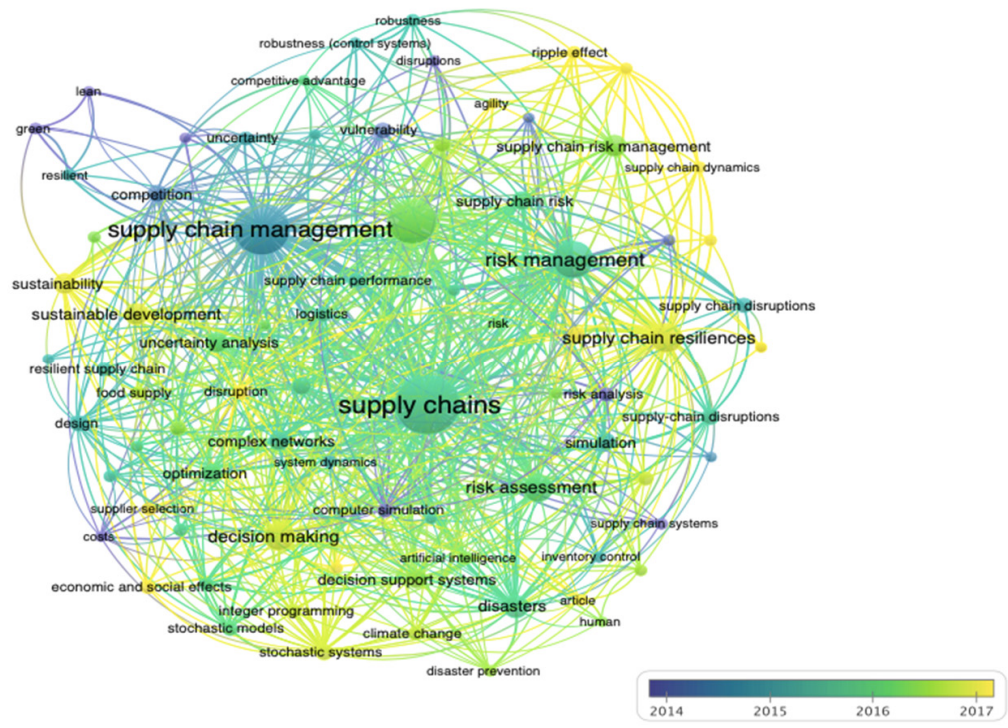

Figure 7. Evolution of keyword relationships used in that research. VOSviewer software.

The relational analysis of keywords on resilience management with sustainability in supply chains shows that it is a topic of a recent study in the last five years, where the main analysis has focused on unifying common criteria for its management. Sustainability is strongly related to the terms: supply chain design, supplier selection, economic and social impacts, lean, green, and agile management, climate change and environmental management, logistics, agri-food supply chains, and supply chain performance management. In these terms, resilience management is also directly relevant for analysis.

\subsection{Capabilities, Principles, Strategies, and Elements of Resilience in the Supply Chain}

The resilience management analysis identifies five capabilities that supply chains must develop. For their description, the research by Ali et al. (2017) [31] is adapted according to the definition proposed in the previous section. The five capabilities are identified as follows.

1. Prevention: The ability to identify and anticipate the occurrence of disruptive events by implementing processes and activities to strengthen the activities with higher risks.

2. Resistance: The ability to resist the effects of the disturbances without losing control of the situation, adjusting critical resources effectively. Implementing resilience actions such as increased flexibility and redundancy will minimize the consequences of these [30].

3. Response: The capability to develop activities to respond to disruptive actions in an agile and efficient manner, minimizing the consequences of expansion from the main node to the other nodes. 
4. Recovery and continuity: The ability to return to normal supply chain activities or a better state after the occurrence of the disruption. It is necessary to analyze the market after the disruptive event and adapt the business to the new market needs.

5. Learning and continuous improvement: The ability to analyze the disruptive event, its causes, and impacts and to establish actions needed to avoid a new occurrence.

In the literature review, several papers develop an analysis to achieve the definition of the principles and elements of resilience, but there is a disparity in the terminology used. To refer to the elements, some papers consider other terms such as capabilities, enablers [2], and enhancers [162]. In this research, the resilience principles proposed by Christopher and Peck (2004) and Ali et al. (2017) [31,46], widely cited in the literature, were taken as a starting point. They proposed four principles. Each principle has its elements in parentheses: (1) Supply chain re-engineering (redundancy and flexibility); (2) collaboration (information sharing and trust); (3) agility (visibility and velocity); (4) supply chain risk management (SCRM) culture (leadership and innovation).

Based on the principles and elements described by Christopher and Peck (2004) and Ali et al. (2017) [31,46], an analysis of the articles was developed to extend their proposal. The results were summarized in Table A2 of the Appendix A. The new elements of resilience identified are: Robustness [30-33,137,138,163-167]; contingency planning [2,31-33,37,137,157,167-170]; disruptive environment awareness [29,31,33,37,157,165,169-171]; knowledge management [29,31-33,37,163,165, 169,172]; market adaptation [2,33,163,169,170]; and strategic alignment [32,173].

Then, a relationship was made between the elements and the principles (Figure 8). The four principles are linked together by arrows to establish a joint action for the supply chain resilience management. Regarding the elements, robustness and contingency planning were incorporated into the principle of supply chain re-engineering. Robustness and contingency planning help maximize the benefits of flexibility and redundancy, and increase the supply chain's ability to maintain normal operations after a disruptive event $[31,165]$. Strategic alignment is added to the principle of collaboration, as it the system's ability to integrate business objectives and coordinate the way actions are implemented [32,173]. Strategic alignment is based on the elements of shared information and trust among the members of the chain. The market adaptation element was included in the principle of agility, considering that the supply chain generates a response to the disruptive event and competitive strategies adapted to the current or modified market structure (possibly affected by the disruption) and recovers its activity $[2,33,170]$.

The elements of knowledge management and disruptive environment awareness were incorporated into the principle of SCRM culture. These two elements, together with innovation and leadership, allow the members of the supply chain to recognize the existence of possible disruptions and develop actions aimed at avoiding or reducing the effects $[29,31,33,165,170]$. Additionally, based on the experience, these elements generate learning and actions for future situations, including management capability, so that their human resources are trained, coached, and evaluated for increasing performance if a disruptive event happens $[29,31,32,163,169,172]$. The principle of SCRM culture is considered to be transversal to the development of resilient capabilities in supply chains. The action of SCRM elements is necessary to enhance the rest of the principles. Furthermore, SCRM is a factor of great importance for business management from various methodological approaches (lean, agile, green, and sustainability) and is considered a key principle of business success [20,50,80,81,113,174,175].

The scope of the principles and elements of resilience allow for the type of actions that the supply chain should implement in the face of a disruptive event. Implementing the right strategies to increase resilience is of paramount importance to the recovery of the supply chain. Hollnagel (2011) [176] divides the strategies into three types depending on the phase of the disruption: (1) Proactive, (2) concurrent, and (3) reactive. 


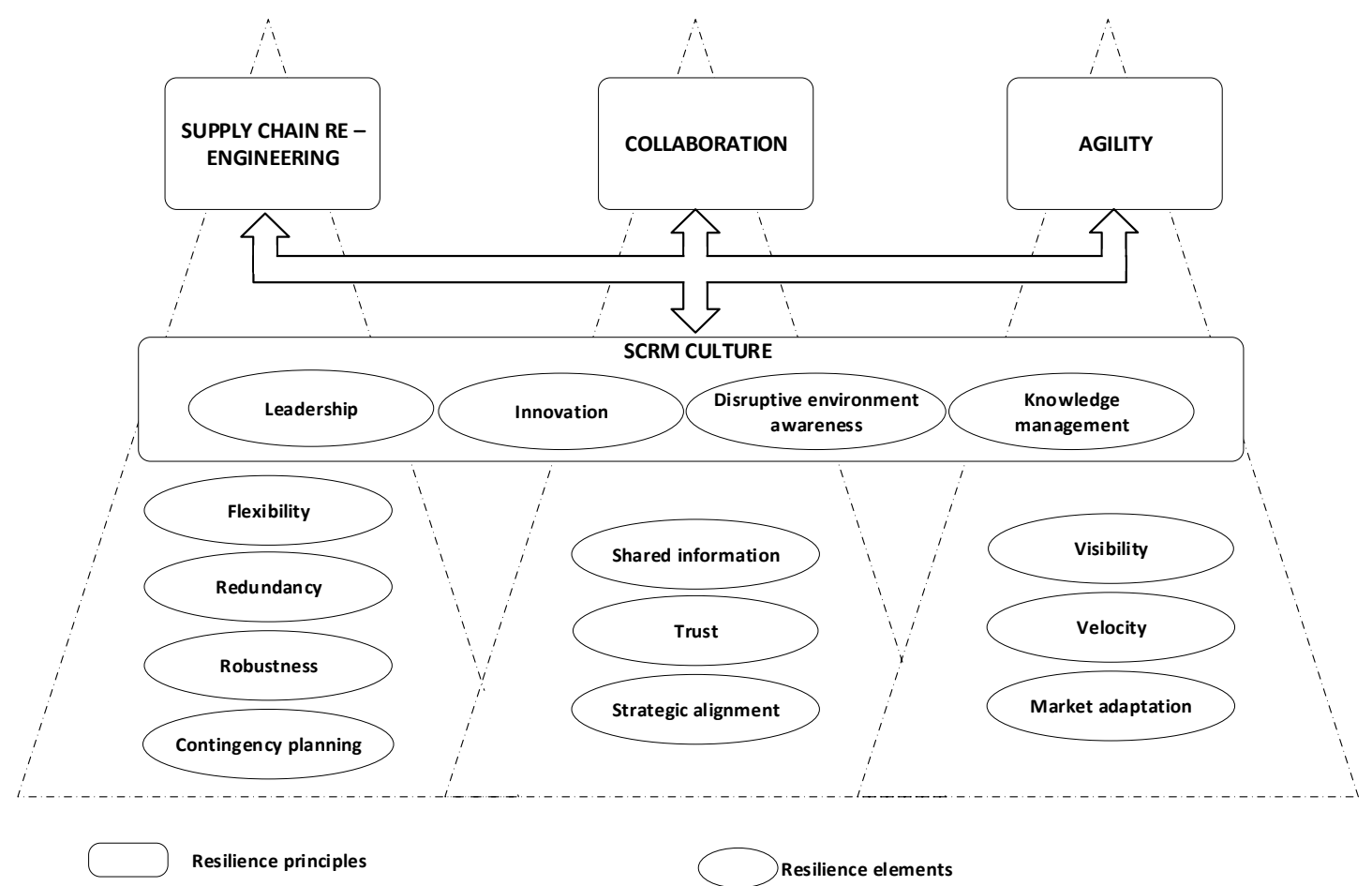

Figure 8. Principles and elements of resilience in the supply chain. Based on Christopher and Peck (2004) and Ali et al. (2017) [31,46].

Proactive strategies are developed in the pre-disruption phase, when supply chain prevention capability is activated. This type of strategy analyzes the environment, establishes potential disruptive events, plans actions, and prepares for a disruption [160]. Concurrent strategies correspond to chain resistance and rapid response actions, that is, the first actions taken when a disruptive event occurs [47]. These strategies are associated with the principles of supply chain re-engineering, collaboration, and agility proposed by [46]. The latter strategies correspond to the post-disruptive event strategies. They include recovery, learning, and continuous improvement. The aim is to return to the original state of the supply chain or to a better state by adapting the business to the market $[106,177]$. These relationships are shown in Figure 8.

\subsection{Supply Chain Risks}

The supply chain can be affected by disruptive events. The consequences generated by these events on its operations cause unforeseen changes and impacts on the other members of the supply chain [46]. The level of impact depends on the level of vulnerability of the supply chain. Vulnerability is defined as the predisposition of the risk sources and factors to exceed the mitigation strategies developed by the supply chain and to cause losses and adverse consequences to the system [178]. So, vulnerability must be identified and analyzed together with all members of the supply chain to propose strategies. Vulnerability is related to the characteristics of density, criticality, and complexity of the node, given that it increases the probability and severity of being affected if there is a disruptive event $[173,179]$. The vulnerability analysis allows us to evaluate the current structure of the supply chain and propose actions to reduce the consequences of potential disruptive events.

Density refers to the concentration of activities carried out by one node of the supply chain [33]. The density of the node varies depending on the key strategies it executes, such as the type of supply, market, or type of production (concentrated or diversified) [173]. Criticality refers to the preparation of the node to face a disruptive event, and complexity refers to the difficulty of the operational process that the node must maintain when a disruptive event occurs [162,173]. Thus, there will be nodes in the supply chain that have priority for the development of resilient strategies. Vulnerability then depends 
on the design and characteristics of the supply chain, and the probability depends on the type of risk affecting the supply chain [59].

The risks affecting the supply chain have been classified from different perspectives. Christopher and Peck (2004) consider three types of risks: (1) Internal to the company, including process and control; (2) external to the company, but internal to the supply chain, such as demand or supply; and (3) external risks related to the environment [46]. Tang and Tomlin (2008) consider five types of risks that can disrupt the supply chain: (1) Supply; (2) process; (3) demand; (4) intellectual property; and (5) behavioral, political, and social [44].

For this research, the classification proposed by Mital et al. (2018) [112] is mainly used, incorporating some aspects of Christopher and Peck (2004) and Tang and Tomlin (2008) [44,46]. Mital et al. (2018) [112] classifies the risks into five categories: (1) Demand, (2) supply, (3) regulatory, legal, and bureaucratic; (4) infrastructure, and (5) critical. Similarly, it was considered to include subcategories within the division to group the perspectives of the risks in the papers analyzed.

With this classification, the analysis of the papers results in 145 papers considering the type of risk $(62.50 \%)$. In this percentage, the type of risk with the highest consideration corresponds to the supply. Specifically, procurement (price fluctuations and availability of supplies) is the one with the greatest percentage weight. This is related to the relationship between the supplier-manufacturer, and shows the criticality of this interface in the supply chain. The second category corresponds to critical risks. The lack of capability of the supply chain to anticipate their occurrence makes their consequences high impact and even decisive for the continuity of the business. The third category with the highest consideration is infrastructure risks, given the disruptions that may occur to the organization's internal processes, such as equipment, additional services, and information and communication technology problems among its members. This fact is related to the importance of the principle of collaboration (shared information, trust, and strategic alignment) to reduce the possible consequences of a disruptive event in the system [33]. Demand risks appear in lesser proportion. The last category considered is regulatory, legal, and bureaucratic where supply chain operations adapt to changes in government and socio-environmental policies. The results are shown in Table 7, where the second column refers to the percentage of papers that consider the risk category in their study, based on a base of 145 papers. A paper can analyze more than one risk category, so that the sum of the percentages does not result in $100 \%$. Each risk category was divided into subcategories for a more specific analysis, presented in the fourth column of the table. For example, supply risk is divided into three more specific subcategories. Similarly, the sum of the percentage of the category is not $100 \%$, since a paper can analyze more than one subcategory of the risk.

Managing resilience requires an assessment of the type of risk and vulnerability in the supply chain. The supply chain risk assessment should consider the probability and consequences of the disruptive event occurring [180,181]. Ho et al. (2015) develop a review of the literature on supply chain risk management, agreeing on the variables of analysis for risk assessment [182]. The authors analyze the main techniques for risk assessment and propose rating scales such as the probability-impact matrix. Kleindorfer and Saad (2005) [45] cited by Behzadi et al. (2018) [36], divide risk into only two types of categories: Low probability high consequence events (LPHC) and high probability low consequence events (HPLC). For this research, we will consider dividing the risk into four types according to impact and probability of occurrence: Low probability high consequence events (LPHC), low probability low consequence events (LPLC), high probability low consequence events (HPLC), and high probability high consequence events (HPHC). 
Table 7. Risk classification. Source: Adapted from [44,46,112].

\begin{tabular}{|c|c|c|c|}
\hline Risk Category & $\begin{array}{c}(\%) \\
(n=145)\end{array}$ & Risk Subcategory & $(\%)$ \\
\hline \multirow[b]{2}{*}{ Supply } & \multirow{2}{*}{$\begin{array}{c}76.55 \% \\
\text { (111 papers) }\end{array}$} & Procurement: Price fluctuations and availability of supplies & $76.58 \%$ \\
\hline & & $\begin{array}{l}\text { Interruptions in internal processes: Lack of quality, safety, inventory } \\
\text { fluctuations, and labor strikes }\end{array}$ & $23.42 \%$ \\
\hline \multirow{5}{*}{ Critical } & \multirow{5}{*}{$\begin{array}{c}29.66 \% \\
(43 \text { papers })\end{array}$} & Supply: Problems in logistics and distribution & $39.64 \%$ \\
\hline & & Terrorist attacks & $86.05 \%$ \\
\hline & & Socio-political disturbances & $25.58 \%$ \\
\hline & & Natural disasters & $11.63 \%$ \\
\hline & & Epidemics and pandemics & $25.58 \%$ \\
\hline \multirow[t]{2}{*}{ Infrastructure } & \multirow{2}{*}{$\begin{array}{l}27.59 \% \\
(40 \text { papers })\end{array}$} & Internal processes interruptions: Equipment and additional services. & $82.50 \%$ \\
\hline & & Information and communication technology problems & $32.50 \%$ \\
\hline \multirow[t]{2}{*}{ Demand } & \multirow[t]{2}{*}{$\begin{array}{c}17.24 \% \\
\text { (25 papers) }\end{array}$} & Unforeseen or unstable demand & $92.00 \%$ \\
\hline & & Market: Competition and price fluctuations & $24.00 \%$ \\
\hline \multirow[t]{2}{*}{$\begin{array}{c}\text { Regulatory, } \\
\text { legal and } \\
\text { bureaucratic }\end{array}$} & $\begin{array}{c}7.59 \% \\
\text { (11 papers) }\end{array}$ & Government policy change: Imports, exports, transport & $72.73 \%$ \\
\hline & & Environmental and social policy changes & $54.55 \%$ \\
\hline
\end{tabular}

\subsection{Sustainability Dimensions}

Supply chain management relies on the strategic objectives set by all its members. These strategic objectives are transformed into operational objectives that can respond to different aspects such as sustainability, resilience, etc. [183]. From the literature reviewed, 16 papers (6.89\%) develop a joint analysis incorporating sustainability and resilience. Table 8 presents a classification of the articles according to the dimensions of sustainability (economic, social, and environmental) that they consider, being classified in Economic-Social (E-S), Economic-Environmental (E-EN), or Triple Bottom Line (TBL) when they consider the three dimensions.

Table 8. Relationship between sustainability dimensions and resilience elements.

\begin{tabular}{|c|c|c|c|c|}
\hline \multirow{2}{*}{ Article } & \multicolumn{3}{|c|}{ Sustainability } & \multirow{2}{*}{ Resilience Elements } \\
\hline & E-S & E-EN & TBL & \\
\hline [50] & & $\checkmark$ & & $\begin{array}{c}\text { Flexibility, velocity, market adaptation, redundancy, contingency planning, } \\
\text { technology, shared information }\end{array}$ \\
\hline [119] & & $\checkmark$ & & Flexibility, redundancy \\
\hline [8] & & & $\checkmark$ & Robustness, redundancy \\
\hline [14] & & & $\checkmark$ & Flexibility, redundancy, robustness, contingency planning \\
\hline [140] & & $\checkmark$ & & Flexibility, shared information, visibility \\
\hline [183] & & & $\checkmark$ & Flexibility, shared information, visibility, velocity \\
\hline [23] & & & $\checkmark$ & Flexibility, shared information, visibility, velocity \\
\hline [62] & & $\checkmark$ & & Redundancy \\
\hline [11] & & & $\checkmark$ & Flexibility, redundancy, \\
\hline [16] & & $\checkmark$ & & Robustness, redundancy \\
\hline [92] & & $\checkmark$ & & Robustness \\
\hline [93] & & & $\checkmark$ & Flexibility, redundancy \\
\hline [184] & & & $\checkmark$ & Flexibility, redundancy, shared information, market adaptation \\
\hline [185] & & & $\checkmark$ & Redundancy, contingency planning \\
\hline [186] & & & $\checkmark$ & Flexibility, redundancy, robustness, leadership \\
\hline [187] & & & $\checkmark$ & Flexibility, redundancy, shared information, trust, leadership, innovation \\
\hline
\end{tabular}

As can be observed in the table, joint analysis has been carried out over the last six years. This shows that supply chain strategies are changing and are more focused on improving their sustainability and resilience performance together. First, as happens with other approaches, the environmental dimension of sustainability was incorporated into integrated supply chain resilience 
management [50,119]. From 2016 onwards, the social dimension is also incorporated by considering the TBL. In total, 6 papers $[16,50,62,92,119,140]$ integrate the economic-environmental dimensions, and 10 papers incorporate the TBL dimensions $[8,11,14,23,93,183-187]$. No research was found that only analyzes the economic-social relationship.

Each pillar of sustainability is measured by criteria. Table 9 presents a classification of papers based on the criteria of each dimension that have been extracted from the literature $[42,188,189]$.

Table 9. Criteria for the three dimensions of sustainability. Source: Based on $[42,188,189]$.

\begin{tabular}{|c|c|c|c|c|c|c|c|c|c|c|c|c|c|c|c|c|c|}
\hline \multicolumn{2}{|c|}{ Sustainable Criteria } & \multicolumn{16}{|c|}{ Articles } \\
\hline & & \multirow{2}{*}{$\begin{array}{c}\text { [50] } \\
\checkmark\end{array}$} & \multirow{2}{*}{$\frac{\text { [119] }}{\checkmark}$} & \multirow{2}{*}{$\frac{[8]}{\checkmark}$} & \multirow{2}{*}{$\frac{\text { [14] }}{\checkmark}$} & \multirow{2}{*}{$\frac{[140]}{\checkmark}$} & \multirow{2}{*}{$\frac{[183]}{\checkmark}$} & \multirow{2}{*}{$\frac{\text { [23] }}{\checkmark}$} & \multirow{2}{*}{$\frac{[62]}{\checkmark}$} & \multirow{2}{*}{$\frac{\text { [11] }}{\checkmark}$} & \multirow{2}{*}{$\frac{\text { [16] }}{\checkmark}$} & \multirow{2}{*}{$\frac{\text { [92] }}{\checkmark}$} & \multirow{2}{*}{$\frac{\text { [93] }}{\checkmark}$} & \multirow{2}{*}{$\frac{\text { [184] }}{\checkmark}$} & \multirow{2}{*}{$\frac{\text { [185] }}{\checkmark}$} & \multirow{2}{*}{$\frac{\text { [186] }}{\checkmark}$} & \multirow{2}{*}{$\frac{[187]}{\checkmark}$} \\
\hline Economic/business & $\begin{array}{l}\text { Strategic and } \\
\text { Organization }\end{array}$ & & & & & & & & & & & & & & & & \\
\hline & Financial situation & & & $\checkmark$ & & & $\checkmark$ & $\checkmark$ & $\checkmark$ & & $\checkmark$ & & $\checkmark$ & & $\checkmark$ & & \\
\hline & Cost & $\checkmark$ & $\checkmark$ & $\checkmark$ & $\checkmark$ & $\checkmark$ & $\checkmark$ & $\checkmark$ & $\checkmark$ & $\checkmark$ & $\checkmark$ & $\checkmark$ & $\checkmark$ & & $\checkmark$ & $\checkmark$ & $\checkmark$ \\
\hline & $\begin{array}{l}\text { Technological and } \\
\text { communication } \\
\text { integration }\end{array}$ & & $\checkmark$ & $\checkmark$ & $\checkmark$ & & & $\checkmark$ & $\checkmark$ & $\checkmark$ & $\checkmark$ & $\checkmark$ & $\checkmark$ & $\checkmark$ & $\checkmark$ & $\checkmark$ & $\checkmark$ \\
\hline & Quality & $\checkmark$ & $\checkmark$ & $\checkmark$ & $\checkmark$ & $\checkmark$ & $\checkmark$ & $\checkmark$ & $\checkmark$ & $\checkmark$ & $\checkmark$ & $\checkmark$ & $\checkmark$ & $\checkmark$ & $\checkmark$ & $\checkmark$ & $\checkmark$ \\
\hline & $\begin{array}{l}\text { Reputation and } \\
\text { market structure }\end{array}$ & & $\checkmark$ & $\checkmark$ & $\checkmark$ & $\checkmark$ & $\checkmark$ & & & & & $\checkmark$ & $\checkmark$ & & $\checkmark$ & & \\
\hline \multirow{6}{*}{ Environmental } & Water consumption & & & & $\checkmark$ & & $\checkmark$ & & $\checkmark$ & $\checkmark$ & & & & & & & \\
\hline & Energy consumption & $\checkmark$ & $\checkmark$ & $\checkmark$ & $\checkmark$ & & $\checkmark$ & $\checkmark$ & $\checkmark$ & $\checkmark$ & & $\checkmark$ & & $\checkmark$ & & & $\checkmark$ \\
\hline & $\begin{array}{l}\text { Raw material } \\
\text { consumption }\end{array}$ & $\checkmark$ & $\checkmark$ & & $\checkmark$ & $\checkmark$ & $\checkmark$ & & $\checkmark$ & $\checkmark$ & $\checkmark$ & & & & $\checkmark$ & & $\checkmark$ \\
\hline & Pollution prevention & $\checkmark$ & $\checkmark$ & $\checkmark$ & $\checkmark$ & $\checkmark$ & $\checkmark$ & $\checkmark$ & $\checkmark$ & $\checkmark$ & & $\checkmark$ & $\checkmark$ & $\checkmark$ & $\checkmark$ & $\checkmark$ & $\checkmark$ \\
\hline & $\begin{array}{l}\text { Pollution control } \\
\text { Environmental }\end{array}$ & $\checkmark$ & & & $\checkmark$ & & $\checkmark$ & $\checkmark$ & $\checkmark$ & $\checkmark$ & $\checkmark$ & $\checkmark$ & $\checkmark$ & $\checkmark$ & $\checkmark$ & $\checkmark$ & $\checkmark$ \\
\hline & $\begin{array}{l}\text { product performance } \\
\text { (waste) }\end{array}$ & $\checkmark$ & $\checkmark$ & & & $\checkmark$ & $\checkmark$ & & $\checkmark$ & $\checkmark$ & & & $\checkmark$ & $\checkmark$ & & & \\
\hline \multirow[t]{7}{*}{ Social } & $\begin{array}{l}\text { Commitment and } \\
\text { community support }\end{array}$ & & & $\checkmark$ & $\checkmark$ & & & $\checkmark$ & & $\checkmark$ & & & $\checkmark$ & $\checkmark$ & $\checkmark$ & & \\
\hline & $\begin{array}{l}\text { Stakeholders } \\
\text { involvement }\end{array}$ & & & $\checkmark$ & & & $\checkmark$ & $\checkmark$ & & & & & & $\checkmark$ & & & $\checkmark$ \\
\hline & $\begin{array}{l}\text { Occupational health } \\
\text { and safety }\end{array}$ & & & & $\checkmark$ & & & & & $\checkmark$ & & & $\checkmark$ & & & & $\checkmark$ \\
\hline & $\begin{array}{c}\text { Wages and working } \\
\text { hours }\end{array}$ & & & & $\checkmark$ & & & & & & & & $\checkmark$ & & & $\checkmark$ & \\
\hline & Staff satisfaction & & & & $\checkmark$ & & & & & $\checkmark$ & & & & & & $\checkmark$ & \\
\hline & $\begin{array}{l}\text { Training of } \\
\text { employees }\end{array}$ & & & & $\checkmark$ & & & & & $\checkmark$ & & & & & & $\checkmark$ & \\
\hline & $\begin{array}{c}\text { Discrimination and } \\
\text { diversity }\end{array}$ & & & & & & & & & $\checkmark$ & & & & & & & \\
\hline
\end{tabular}

In the economic/business dimension, all articles consider strategic, organization, and quality criteria. These criteria are the most analyzed in sustainability management. Cost criteria is considered sometimes as a constraint in the implementation of sustainability in supply chains $[23,93]$. Technological and communication integration criteria have been given greater consideration in recent years and have become a primary point of analysis given the interoperability requirements in supply chains [187]. To a lesser extent, the financial situation, reputation, and market structure criteria are considered. This last criterion provides an intangible asset for organizations that allows them to analyze the context of the supply chain to manage sustainability more efficiently [185].

In the environmental dimension, the criteria that are most considered for sustainability management are pollution prevention and pollution control focused on maintaining a production that minimizes the emissions of pollutants. In recent years, the study has focused on anticipating techniques that control the pollutants. These criteria are regulated, and their compliance is required to different degrees depending on the sector [62]. Water, energy, and raw material consumption are also considered for the analysis, with energy and raw material consumption being the most widely used. This is due to the stronger restrictions and higher costs generated by their use [92]. Environmental product performance (waste) is a criterion considered in half of the papers. Analysis of how to manage the waste after customer use and its relationship to performance and sustainability and resilience management appears in recent papers $[93,190]$. 
With regard to the social dimension, papers deal with social criteria, but to a lesser extent than economic and environmental criteria. Commitment and community support and stakeholder involvement are the criteria with the most analysis. Stakeholder involvement will allow the strategic and operational objectives to be established closer to the reality of the community and society [184]. The criteria occupational health and safety, wages and working hours, staff satisfaction, and training of employees are few considered in establishing relationships between sustainability and resilience, and only one paper considers discrimination and diversity of employees [11]. As for corporate social responsibility, although several papers consider the social dimension, only two papers identify it explicitly [183,186].

The resilience elements that are most discussed that integrate sustainability and resilience in supply chains are: Flexibility, redundancy, and robustness (Table 8). These elements allow companies to adopt strategies and actions that optimize the capacity to react and recover from disruptive events, but decrease the effectiveness of sustainable actions [8]. In reality, there are sustainable actions that can dramatically minimize the resilience of the supply chain. The main sustainability practices focus on the efficient use of resources and promote the significant reduction of redundancies, mainly through the elimination of inventory and safety stock in the supply chain $[14,16]$. While these strategies are in line with the principles of economic and environmental sustainability, they increase the vulnerability of the chain to a ripple effect when faced with a disruption [191]. Similarly, the sustainability criteria for supplier selection supports the need to generate business relationships with suppliers that meet sustainable criteria, reducing the possibility of working with other types of suppliers in the resistance stage when a disruptive event occurs [16]. For this reason, supply chains tend to decrease the level of compliance with sustainability objectives while dealing with unexpected disruptive events, especially those considered critical [50]. This makes it necessary that, from the design stage, supply chains are sufficiently resilient to maintain the same sustainability when a disruption occurs [140].

\section{Conceptual Framework to Manage Resilience and Increase Sustainability in the Supply Chain}

Resilience management in the supply chain is characterized by its multidimensionality and complexity [160]. This paper proposes a conceptual framework for analyzing and managing resilience to increase sustainability in the supply chain. The proposed framework is illustrated in Figure 9 and is structured in three building blocks: Performance management, risk, and resilience in the supply chain. 


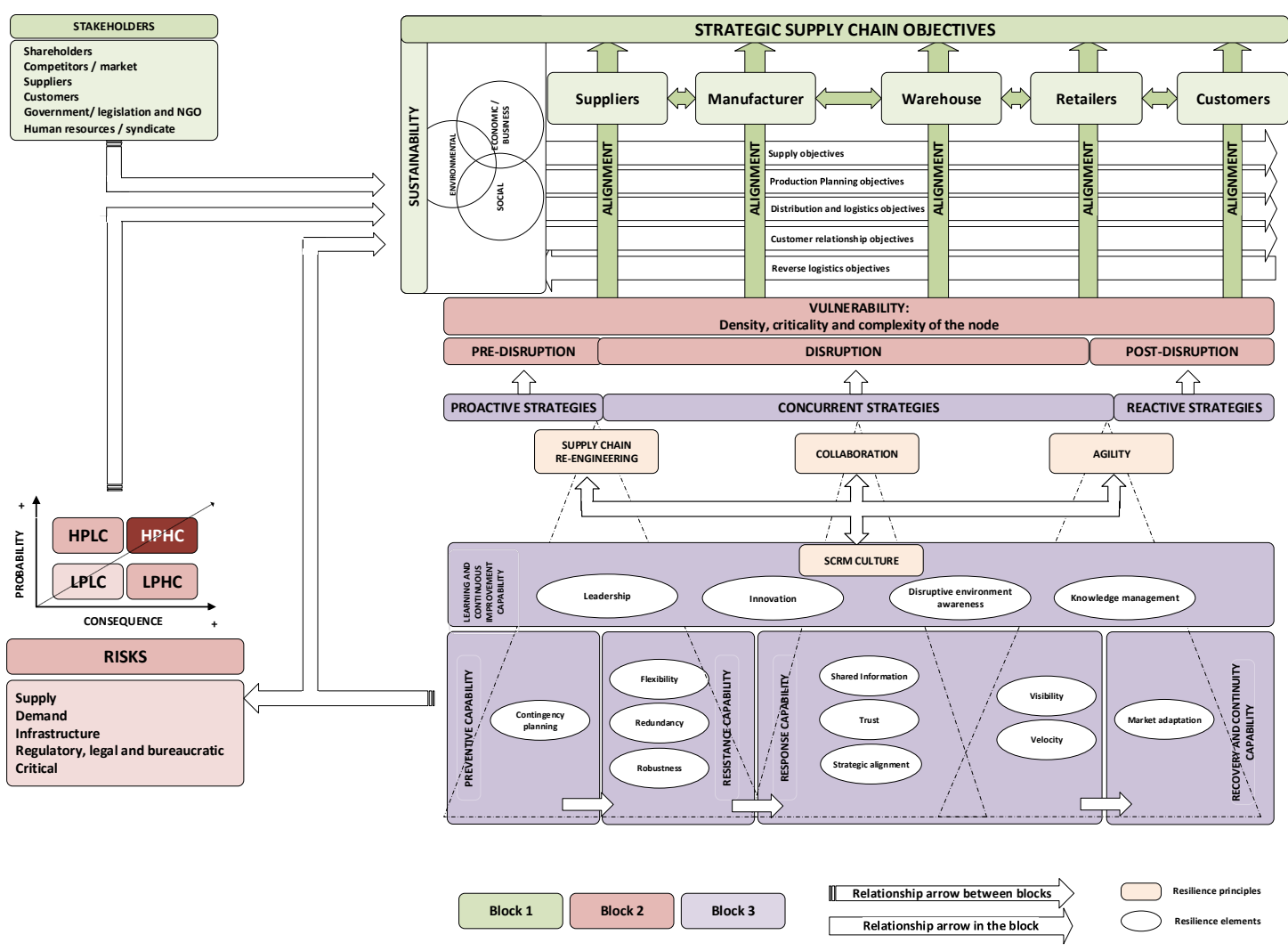

Figure 9. Conceptual framework for supply chain resilience. Based on Christopher and Peck (2004), Ali et al. (2017a), Mital et al. (2018), and Stone and Rahimifard (2018). [31,33,46,112].

\subsection{BUILDING BLOCK 1: Performance Management}

To manage supply chain performance comprehensively, it is necessary to consider the nodes (participating organizations), the different stakeholders involved, and the strategy (operationalized in strategic and process objectives of the supply chain) [192,193].

\subsubsection{Physical View Elements and Strategic Objectives}

The first block of the proposed framework represents the members (nodes) of the supply chain. Each of these nodes pursues intra-organizational objectives. In the figure, five nodes are represented, but this number may be different when considering suppliers of suppliers, various warehouses, different retailers, or even different customer focus groups. Each node is linked by a double arrow representing the flow of materials, information, and money.

Generally, companies set their objectives in isolation, and these objectives must be adapted and aligned with the strategic objectives established for the global supply chain $[2,32,46,173]$. These objectives should incorporate the three types of sustainability objectives coming from the economic, environmental, and social dimensions, as well as the objectives to manage the resilience elements.

\subsubsection{Key Processes and Performance Management}

In addition to pursuing strategic supply chain objectives, there is a need to manage key processes $[192,193]$. The objectives of these processes must be defined and aligned with the strategic objectives; they must also consider the three dimensions of sustainability. Key processes can be strategic, tactical, or operational, and their objectives must be defined jointly by all members of the supply chain $[31,163,194]$. In the figure, the linear arrows that cross all the nodes of the system indicate the identification, evaluation, and prioritization of the processes to establish a follow-up system. In each 
node, it must be clear which part of the process is developed, what type of control it must exert, and what input and output the other members of the chain expect $[33,173]$.

\subsubsection{Stakeholders}

In defining the strategic objectives of the supply chain and key processes, it will be necessary to consider the system's stakeholders [31,166]. Stakeholders influence the definition and alignment of objectives, and it is necessary to correctly identify their expectations and requirements for their transfer and integration into strategic planning [31,192,193]. Stakeholders involve shareholders, competitors/markets, suppliers, customers, government, NGOs, unions, workers, etc.

In defining sustainability objectives, stakeholders are crucial. Public policies and government regulations combine various criteria of obligatory compliance in the economic, social, and especially environmental dimensions

\subsection{BUILDING BLOCK 2: Supply Chain Risk}

Supply chain risk is determined by the probability of occurrence of an event and the consequences of its actions $[30,112,178]$. The consequences will be limited by the vulnerability of the processes at each of the nodes and the relationships between the interfaces of the supply chain members $[158,179]$. Figure 9 represents the vulnerability under the characteristics of density, criticality, and complexity of the node, allowing us to establish which node should be prioritized to minimize the consequences of the disruption. The probability of occurrence depends on the type of risk analyzed [2,59].

Within this framework, the division into five types of risks was established: Supply, demand, infrastructure, regulatory, legal and bureaucratic, and critical. Supply, infrastructure, and demand risks are internal risks to the supply chain, although some require actions that are difficult to control internally [44]. Serious regulatory, legal, and bureaucratic risks are external to the supply chain.

With the analysis of probability and consequence [100,180-182], and considering that the type of risk can be an LPLC, HPLC, LCHP, and HPHC event in the proposed framework. The main resilient strategies should focus on the types of HPHC risks that it causes to the supply chain $[100,181,182]$. HPHC events affect the supply chain as a whole and generate a change in the functional structure, even changing its value chain, so that action is immediate. The LPHC risks should be also carefully monitored in the short term due to the high impact that they can produce. The HPLC risks must be analyzed in the medium term, prioritizing the type of effect that occurs in the central node of the supply chain. Therefore, it is necessary to highlight the vulnerability of the nodes to prioritize actions. LPLC events are analyzed in the long term considering their evolution in the members' operations. Identifying and managing potential risks and their consequences will then enable the supply chain to manage its key processes when a disruptive event occurs.

Deploying a process vision in the supply chain allows identifying the type of consequence that would occur if an event happens in each of the nodes and interfaces of the chain, allowing its members to modify their individual and global actions to minimize the consequences of the impacts $[30,59,195]$.

This block is joined using a simple arrow to the performance management block since the consequences generated, depending on the type of risk, negatively affect the achievement of the sustainable objectives and resilience capabilities of the supply chain [192,193].

\subsection{BUILDING BLOCK 3: Supply Chain Resilience}

The third building block of the framework represents supply chain actions to manage resilience. Strategies developed should be aligned to avoid or minimize the consequences of a disruptive event $[31,32]$. These strategies fall under the operational objectives of each of the nodes and interfaces of the supply chain members, where an alignment between the intra-organizational objectives and the strategic objectives of the supply chain is needed. This relationship is represented in Figure 9 by a unidirectional arrow from the types of resilience strategies to the process objectives, and these in turn are aligned to the strategic objectives of the supply chain [196]. Similarly, the strategies are linked to 
risk characterization. It is necessary to analyze the vulnerability of the nodes through the analysis of the density, criticality, and complexity of the node.

Hollnagel (2011) classifies the strategies into three types depending on the phase of interruption: (1) Proactive, (2) concurrent, and (3) reactive [176]. These strategies must be congruent with the stages of a disruptive event: Proactive strategies in the pre-interruption stage, concurrent strategies in the interruption stage, and reactive strategies in the post-interruption stage [31]. By developing each of these strategies, resilient supply chain capabilities are strengthened, and each of these capabilities strengthens one or more principles and their elements. There is a cause-effect relationship between strategies and resilience capabilities and sustainable objectives, that is, implementing strategies strengthens capabilities and impact on objectives, which, in turn, will allow for more efficient actions when a supply chain disruption occurs $[2,31,33]$.

The learning and continuous improvement capability, linked to the principle of SCRM culture, establishes elements of resilience in a transversal manner for all strategies applied in the supply chain. The elements: Knowledge management, innovation, leadership, and disruptive environment awareness allow the creation of awareness and meaningful learning from the disruptive event that occurred at each stage and ultimately generate meaningful learning for future events $[31,37,165]$, and increase the success of sustainability management in supply chains [186]. Innovation enables the development of creative ideas to implement proactive, concurrent, and reactive actions that strengthen resilience and sustainability in the supply chain [33].

Proactive strategies are associated with the contingency planning element. Their connection with the supply chain risk building block allows, through the disruptive environment awareness element, to foresee the possibilities of the occurrence of an event and its possible effects $[33,46,170]$. This activates the capability for prevention with contingency planning considering the process and strategic objectives of the entire supply chain (strategic alignment) and the implementation of proactive strategies to eliminate or reduce the impacts that it may generate $[31,33]$. The type of risk that is anticipated and its probability make it possible to establish what type of actions should be implemented in the supply chain [59].

For increasing resilience to disruption, the key elements are flexibility, redundancy, and robustness $[2,31,46]$. Flexibility as an element has been widely studied, and the strategies proposed to cover both intra-organizational and supply chain actions: Flexibility in production, procurement, and distribution $[29,33,44,165]$. Flexibility and redundancy, strengthened by the principle of supply chain robustness [197], will minimize the consequences of a system disruption more efficiently. It is important to analyze the scope of these elements, since they can be opposed to other methodologies such as lean, agile, or green, by raising operating costs and increasing the level of waste at the node interface [20].

Flexibility and redundancy allow minimizing the first consequences of the event, but collaboration and agility principles are needed for more efficient action [31,46]. Visibility and velocity, as agility's elements, will allow to analyze the scenario where the supply chain is located and to establish the concurrent strategies focused on the supply and inventory needed to face it $[101,174,198,199]$. It is highly important to consider information sharing and trust in the use of this information to know what resistance actions should be applied in the supply chain when it is disrupted.

After facing the direct consequences, reactive strategies are activated, and the contingency plan is implemented, for which it is necessary to analyze the current market situation and adapt the business to it $[2,169,170]$. This action may include a change in the supply chain structure, or the strategic objectives initially set [163]. To do this, it is necessary to establish and maintain up-to-date measurement metrics (KPIs) in the supply chain to support decision making.

For this reason, the elements initially identified within supply chain re-engineering, collaboration, agility, and SCRM culture principles were incorporated according to the system's ability to recover, learn, and continuously improve if a disruptive event occurs. The interconnected circles between the principles of resilience and the link with the dimensions of sustainability indicate their interrelation 
(interdependence) in their application. Each of the elements needs to be strengthened to efficiently increase the impact of resilient strategies and, consequently, increase sustainability in the supply chain. Strengthening each of the elements is necessary to efficiently increase the impact of the strategies and, consequently, increase the resilience and sustainability in the supply chain $[2,31,33]$.

Strengthening supply chain resilience capabilities generates a positive impact on the achievement of the processes' objectives and, consequently, the system's strategic objectives [163]. But these capabilities also affect risk, minimizing the consequences that it can have on the supply chain members [178]. This cyclical feature of the capabilities enables continuous improvement of the supply chain [31].

The joint analysis of these three building blocks should help to define what to measure and where it is mandatory to prioritize actions. One of the characteristics presented in the literature is the influence of a focal node/company in the supply chain management process with an influence on the other members of the system. The number of key processes, as well as the influence of stakeholders, points out that there is a focal node. Then, identifying it and establishing priority resilience strategies in this node will enable the chain to increase its resilience $[4,87,200]$.

One the one side, it is necessary to focus on identifying the key operational processes, defining the strategic objectives and measurement metrics, which will allow for assessing their status and implementing strategies to help increase resilience in the system [163]. On the other side, objectives and metrics (KPIs) can also be associated with the elements of resilience and dimensions of sustainability to monitor its evolution.

Guidelines for the definition of metrics have not been explicitly defined in the literature reviewed. Instead, the literature does present the definition of a wide variety of objectives. These depend on the focal enterprise and the density, criticality, and complexity of the node and its interactions with the other members of the supply chain where the analysis is developed [11,31,155,163,174,201]. The establishment of these metrics must be related to the objectives and strategies proposed by the supply chain, and must be known and applied in all relevant nodes that must share the information with the rest of the members for joint and realistic decision making.

Based on the supply chain objectives, members should define standardized metrics that support the monitoring of the objectives. In turn, these metrics may need to be adapted to the organization itself $[155,163]$. All members should know what to measure and how to do it, having the same process of information collection and presentation. After individual collection, information needs to be shared by all members for joint decision making [160,163,202,203].

The integration of sustainability and resilience should achieve a compromise solution, and depends on the strategic alignment of supply chain to strategic objectives and operational results [183]. Each node's decision making will depend on the common sustainability and resilience objectives they agree to maintaining in the supply chain. Finding this balance that allows supply chains to maintain sustainability while a disruption occurs is complex, and its application has a significant influence on the overall performance of the supply chain [11].

The ability of supply chains to resist, respond to and recover from disruptive events can become a key feature of maintaining sustainability in the business [183]. This entails the adoption of technological strategies, referring to e.g., Industry 4.0, which allows for the reduction of uncertainty in data management throughout the supply chain and to make more efficient decisions that maintain sustainability during and after a disruptive event in the chain [187].

\section{Conclusions}

Based on the analysis of the previous literature, it was observed that the conceptual frameworks focus on linking the capabilities, principles, and elements of resilience to increase performance in the supply chain. This allows supply chains to establish resilient strategies in the face of disruptive events. But these frameworks do not integrate into a single conceptual framework the type of risks; resilience elements; stakeholders; and performance management system at the strategic and operational levels considering the sustainability dimensions. To address this limitation, a conceptual framework 
is presented that integrates the key components for analysis, measurement, and management of resilience to enhance sustainability in the supply chain. Specifically, the proposed framework integrates stakeholder requirements, supply chain physical structure, performance management at strategic and process levels (including sustainability dimensions), type of risks and resilience capacities, principles, elements, and strategies. The description of the relationships and effects between these components are discussed in the framework.

To support the proposed conceptual framework, an analysis of the conceptual evolution of resilience in supply chains has been developed, including new perspectives from recent years. The conceptual framework introduces the elements of the updated concept. Additionally, the paper, from the review, elaborates an updated classification of the principles and elements of supply chain resilience management.

Furthermore, the proposed conceptual framework links resilient strategies to the dimensions of sustainability, and in the performance of the supply chain, highlighting the importance of joint action in supply chain management.

Based on stakeholder requirements, strategic objectives are defined. Once the strategic level is defined, the key processes are identified, and the objectives of these processes are defined aligned to the strategic level objectives. For both the strategic and process levels, it is necessary to set metrics and goals to assess their status and select strategies that will help increase resilience in the system while seeking to achieve the sustainability dimensions. The resilient elements of the framework can be established as truthful indicators to assess the supply chain in this regard. In this way, the research highlights what would be the relationships between resilience management, sustainability, and performance in supply chains.

\subsection{Limitations}

The literature review, as an exploratory method, was based on peer-reviewed indexed journals from Scopus and ScienceDirect. Publications from books, chapters, conferences, or doctoral dissertations were not considered. The keywords were defined to cover the whole set of words used, but the use of synonyms in the papers could limit the inclusion of articles for the analysis.

Although there is an analysis of the processes and nodes of the supply chain, the research does not differentiate between the size of the companies in the documents analyzed. It does not establish the applicable characteristics of the framework for SMEs and large companies, so the application of the conceptual framework must be validated with different types and sizes of supply chains to obtain their feedback and refine the proposal.

\subsection{Further Research Recommendations}

The proposed framework gives rise to several recommendations for future research. First, to manage inter-organizational performance, it is necessary to define supply chain objectives jointly. Besides, these objectives are associated with indicators that also need to be defined, as well as their relationship with the intra-organizational objectives of each node [204]. This network is complex, since the definition of metrics associated to those indicators must take into account the data aggregation to move from the intra-organizational to the inter-organizational level $[168,205]$. Additionally, it is necessary to establish goals for each indicator to monitor its evolution over time. These goals should be set for both inter- and intra-organizational metrics [192,193]. To manage all the information, it is necessary to consider the mechanisms that support the capture and treatment of the information shared as well as the results of the data analysis. Then, policy definition to share information and the interoperability of information systems and ICTs are relevant issues [31,32,163,169].

Second, the analysis of the density, criticality, and complexity of the node to assess resilience is of recent interest. In this vein, Chowdhury and Quaddus (2017) and Stone and Rahimifard (2018) [33,173] have developed a conceptual analysis considering these characteristics of the nodes, 
but no methodological process is established to define and establish strategies to reduce vulnerability against disruptive events, considering the type and extent of the supply chain [158].

Third, it is necessary to analyze the qualitative and quantitative approaches needed to integrate the data from the three building blocks of the conceptual framework. Although there are studies that analyze the main approaches [36,38], they do not develop a focused analysis integrating the characteristics of the supply chain as well as their impact on performance management.

Fourth, there is a need to investigate the impact of supply chain digitization as a joint strategy between resilience and sustainability. As stated by Ivanov et al. (2019) [95], decision support systems can benefit from integrating big data analytics, industry 4.0, additive manufacturing, and advanced T\&T systems to reduce the ripple effect of disruptive events. It is necessary to establish the impact and relationships of the different digital technologies on the building blocks of the proposed framework. Digitization impacts on the achievement of the objectives of the supply chain and its individual enterprises. It supports the risk assessment process and the strategies to be implemented, increasing the performance of the processes and, therefore, improving the performance of the supply chain. It should be investigated what types of these technologies are a priority for supply chain modeling, process planning, and proactive control of disruption according to the type of chain and risks presented. Besides, the effect of new emerging digital technologies, such as blockchain and omnichannel, on resilience management should be analyzed, which creates new challenges for the application of quantitative analysis techniques in the supply chain ripple effect.

Fifth, further research is needed that deals with the alignment and strengthening of resilient capabilities between upstream and downstream members of the supply chain. All members need to act in the same direction while considering, at the same time, the criticality of each node for priority establishment to develop specific resilient capabilities [32,173]. It may be interesting to strengthen some capabilities in upstream organizations and others in downstream organizations. This analysis also depends on the type of risk and operational processes involved in the supply chain, as established by Kleindorfer and Saad (2005) [45], and what is its influence on the execution of the individual sustainable objectives of each member of the supply chain. Therefore, research should be carried out to analyze the type of resilient capabilities to be strengthened in each member of the supply chain, but aligned with the supply chain, depending on the type of process and vulnerability of the node.

Sixth, the identification of stakeholders influencing supply chain resilience management, as well as the key processes they analyzed, showed that there is little research on the importance of human resource management (soft aspect) in the face of a disruptive event. The researches of Dowty and Wallace (2010), Mandal (2017), and Aviso et al. (2018) [144,172,206] focus on the mitigation of the impacts caused by interruptions in the availability of the workforce, considering that serious events also affect the social and coexistence environment of workers, and therefore to the supply chain sustainability. Further research could be carried out on human resource management before, during and after the disruptive event, in addition to analyzing alternative working mechanisms such as telework or multifunctionality as a reaction mechanism in the supply chain.

Seventh, issues for further analysis would focus on resilience and sustainability management in supply chains where SMEs are involved. Wedawatta et al. (2010) and Ali et al. (2017) [194,207] develop their analysis in SMEs, but they do not generate frameworks for increasing and linking performance management in their supply chains.

SMEs, as identified by Gong et al. (2014), Haraguchi et al. (2016), and Gabler et al. (2017) $[49,208,209]$ require social mechanisms and government support to increase their growth and consolidation in the market. Economic and innovation policies in the countries provide a favorable environment for the strengthening of SMEs and their recovery from a possible disruptive event. A topic for further analysis is the type and form of implementation of government policies or public-private strategies to pass the phase of disruption and complete the reactive phase of resilience in an efficient manner focused on SMEs, following the research $[31,194]$. The applicable type of strategy may be adaptable depending on the economic development and type of economy of the country, becoming 
also a criterion for further analysis. This aspect is out of the scope of the paper, but it will be interesting for further research.

Supplementary Materials: The following are available online at http://www.mdpi.com/2071-1050/12/16/6300/s1, list of papers included in the systematic literature review.

Author Contributions: Conceptualization, A.Z.-A.; M.-J.V. and J.-J.A.-S.; methodology, A.Z.-A. and M.-J.V.; formal analysis, A.Z.-A. and M.-J.V.; investigation, A.Z.-A. and M.-J.V.; writing—original draft preparation, A.Z.-A. and M.-J.V.; writing-review and editing, A.Z.-A.; M.-J.V. and J.-J.A.-S; visualization, A.Z.-A.; supervision, M.-J.V. and J.-J.A.-S.; funding acquisition, M.-J.V. All authors have read and agreed to the published version of the manuscript.

Funding: This study was supported by the Valencian Government in Spain (Project AEST/2019/019).

Conflicts of Interest: The authors declare no conflict of interest. 


\section{Appendix A}

Table A1. Supply Chain Resilience Management. Previous literature review.

\begin{tabular}{|c|c|c|c|c|c|c|c|c|c|c|c|c|c|c|c|c|}
\hline \multirow{3}{*}{ Article } & \multicolumn{4}{|c|}{ Search Criteria } & \multicolumn{5}{|c|}{ Framework } & \multicolumn{7}{|c|}{ Framework Description } \\
\hline & \multirow{2}{*}{ Range } & \multirow{2}{*}{ Articles Analyzed } & \multirow{2}{*}{ Keywords } & \multirow{2}{*}{ Database } & \multirow{2}{*}{$\mathrm{Y}$} & \multirow{2}{*}{$\mathbf{N}$} & \multirow{2}{*}{$\mathrm{CPE}$} & \multirow{2}{*}{ SR } & \multirow{2}{*}{$\mathbf{R}$} & \multirow{2}{*}{$\mathrm{S}$} & \multirow{2}{*}{ PM } & \multicolumn{2}{|c|}{ PMS } & \multicolumn{3}{|c|}{ SUS } \\
\hline & & & & & & & & & & & & SL & OL & ECO & SOC & ENV \\
\hline [27] & Not specified & 74 & "Resilience" and "Resilient SMEs" & Google Scholar & & $\checkmark$ & $\checkmark$ & & & & & & & $\checkmark$ & $\checkmark$ & \\
\hline [4] & Not specified & 134 & Not specified & $\begin{array}{l}\text { HEAL link and Scopus academic } \\
\text { databases }\end{array}$ & & $\checkmark$ & $\checkmark$ & & & & & & & & & \\
\hline [1] & 2000-2013 & 30 & $\begin{array}{l}\text { "Supply chain resilience Resilient supply } \\
\text { chain Resilience/resilient Supply chain } \\
\text { vulnerability, Vulnerability Risk in supply } \\
\text { chain Risk" }\end{array}$ & $\mathrm{ABI} /$ Inform and EBSCO & & $\checkmark$ & $\checkmark$ & $\checkmark$ & & & & & & & & \\
\hline [28] & Not specified & Not specified & Not specified & Not specified & & $\checkmark$ & $\checkmark$ & $\checkmark$ & $\checkmark$ & & $\checkmark$ & & & $\checkmark$ & & \\
\hline [29] & 2003-2013 & 67 & $\begin{array}{l}\text { "supply chain" "resilience," "resiliency," } \\
\text { "resilient" "risk," "security,", "mitigation," } \\
\text { or "business continuity" }\end{array}$ & $\begin{array}{l}\text { EBSCO, ProQuest, ABI/Inform, } \\
\text { Emerald, Science Direct, and } \\
\text { Taylor and Francis, as well as } \\
\text { Google Scholar. }\end{array}$ & & $\checkmark$ & $\checkmark$ & $\checkmark$ & $\checkmark$ & & $\checkmark$ & $\checkmark$ & & $\checkmark$ & & \\
\hline [30] & 2000-2014 & 100 & $\begin{array}{l}\text { "supply chain resilience", "resilient supply } \\
\text { chain", "enterprise resilience", } \\
\text { "organization resilience", and "resiliency in } \\
\text { supply chain". }\end{array}$ & $\begin{array}{l}\text { Business Source Complete, } \\
\text { Engineering Research Database, } \\
\text { Taylor and Francis Online, Google } \\
\text { Scholar, Emerald Insight, and } \\
\text { Science Direct, }\end{array}$ & $\checkmark$ & & $\checkmark$ & $\checkmark$ & & & & & & $\checkmark$ & & $\checkmark$ \\
\hline [35] & 1990 a 2014 & 194 & $\begin{array}{l}\text { "resilience", "management", } \\
\text { "organizations", "business", “enterprise" } \\
\text { "resilience" "resilient" "resiliency". }\end{array}$ & $\begin{array}{l}\text { EBSCOhost, Scopus, Web of } \\
\text { Science e IEEE Explore } \\
\text { EBSCO, Emerald,Science Direct, }\end{array}$ & & $\checkmark$ & $\checkmark$ & & & $\checkmark$ & & $\checkmark$ & $\checkmark$ & & & \\
\hline [31] & 2000-2015 & 103 & $\begin{array}{l}\text { "resilient", "risk", "mitigation", "security" } \\
\text { or "business continuity". }\end{array}$ & $\begin{array}{l}\text { ABI/Inform Global, Web of } \\
\text { Knowledge y Wiley Online } \\
\text { Emerald, Web of Science, }\end{array}$ & $\checkmark$ & & $\checkmark$ & $\checkmark$ & $\checkmark$ & & $\checkmark$ & & & & & \\
\hline [32] & 2000-2015 & Not specified & $\begin{array}{l}\text { "resilience", "supply chain resilience", } \\
\text { "supply chain risk }\end{array}$ & $\begin{array}{l}\text { ABI/INFORM Global, EBSCO, } \\
\text { Science Direct, Taylor \& Francis, } \\
\text { Springer, JSTOR, and SAGE }\end{array}$ & $\checkmark$ & & $\checkmark$ & $\checkmark$ & $\checkmark$ & $\checkmark$ & & & & $\checkmark$ & & \\
\hline [36] & Not specified & 42 & $\begin{array}{l}\text { "risk management," "quantitative risk } \\
\text { management," "supply chain," "operations } \\
\text { re- search," and "agribusiness" } \\
\text { "Community", "Socio-Ecological System" } \\
\text { or "Supply Chain" AND }\end{array}$ & Scopus database & & $\checkmark$ & $\checkmark$ & $\checkmark$ & $\checkmark$ & $\checkmark$ & $\checkmark$ & & & & & \\
\hline [33] & $\begin{array}{l}\text { until } 2016 \\
\text { (included) }\end{array}$ & 137 & $\begin{array}{l}\text { "resilience/resiliency". "Risk/Risk } \\
\text { Management", “OR Vulnerability", “OR } \\
\text { Volatility", “OR Security", "OR Mitigation" } \\
\text { or "OR Business Continuity". "Community" } \\
\text { AND “Resilience" AND "Security". }\end{array}$ & $\begin{array}{l}\text { Google Scholar, Web of Science, } \\
\text { ProQuest, Science Direct, Wiley } \\
\text { Online, Emerald and Scopus }\end{array}$ & $\checkmark$ & & $\checkmark$ & $\checkmark$ & $\checkmark$ & $\checkmark$ & & & & $\checkmark$ & & \\
\hline
\end{tabular}


Table A1. Cont.

\begin{tabular}{|c|c|c|c|c|c|c|c|c|c|c|c|c|c|c|c|c|}
\hline \multirow{3}{*}{ Article } & \multicolumn{4}{|c|}{ Search Criteria } & \multicolumn{5}{|c|}{ Framework } & \multicolumn{7}{|c|}{ Framework Description } \\
\hline & \multirow{2}{*}{ Range } & \multirow{2}{*}{ Articles Analyzed } & \multirow{2}{*}{ Keywords } & \multirow{2}{*}{ Database } & \multirow{2}{*}{$\mathrm{Y}$} & \multirow{2}{*}{$\mathbf{N}$} & \multirow{2}{*}{ CPE } & \multirow{2}{*}{ SR } & \multirow{2}{*}{$\mathbf{R}$} & \multirow{2}{*}{ s } & \multirow{2}{*}{ PM } & \multicolumn{2}{|c|}{ PMS } & \multicolumn{3}{|c|}{ SUS } \\
\hline & & & & & & & & & & & & SL & OL & ECO & SOC & $\overline{\text { ENV }}$ \\
\hline [37] & 2000-2017 & 383 & Not specified & $\begin{array}{l}\text { ABI/Inform Complete, EBSCOhost, } \\
\text { Science Direct, Wiley, Emerald, } \\
\text { Taylor \& Francis, Web of Science } \\
\text { and Google Scholar. }\end{array}$ & $\checkmark$ & & $\checkmark$ & $\checkmark$ & $\checkmark$ & & & $\checkmark$ & & $\checkmark$ & & \\
\hline [34] & 1998-2017 & 309 & $\begin{array}{l}\text { ("information sharing" OR “data sharing") } \\
\text { AND ("supply chain" OR "supply } \\
\text { network") AND (security OR risk OR } \\
\text { protection OR threat OR disruption OR } \\
\text { resilience) }\end{array}$ & Scopus database & & $\checkmark$ & $\checkmark$ & $\checkmark$ & $\checkmark$ & & & & & & & \\
\hline [24] & $2000-2018$ & 54 & $\begin{array}{l}\text { "supply chain resilience", "food chain } \\
\text { resilience", "value chain resilience" } \\
\text { "(SC vulnerability OR supply disruptions) } \\
\text { AND (SC resilience OR SC resiliency)". The } \\
\text { keywords used were "SC resilience", }\end{array}$ & $\begin{array}{l}\text { Science Direct, Scopus and Web of } \\
\text { Science }\end{array}$ & $\checkmark$ & & $\checkmark$ & $\checkmark$ & & $\checkmark$ & $\checkmark$ & & & $\checkmark$ & & \\
\hline [38] & 2002-2017 & 168 & $\begin{array}{l}\text { "resilience supplier", "SC vulnerability", } \\
\text { "supply disruptions", "resilience", "resilient } \\
\text { supply", "SC disruption", "flexibility", } \\
\text { "resilience distribution networks", "supply } \\
\text { resilience strategy", "SC flexibility", } \\
\text { "resiliency in SC", and "enterprise } \\
\text { resilience" }\end{array}$ & $\begin{array}{l}\text { Elsevier, Informs, Springer, Taylor } \\
\text { \& Francis, Emerald, JSTORE, } \\
\text { Inderscience, IEEE. }\end{array}$ & $\checkmark$ & & $\checkmark$ & & $\checkmark$ & & $\checkmark$ & $\checkmark$ & $\checkmark$ & $\checkmark$ & & \\
\hline [26] & 2000-2019 & 157 & 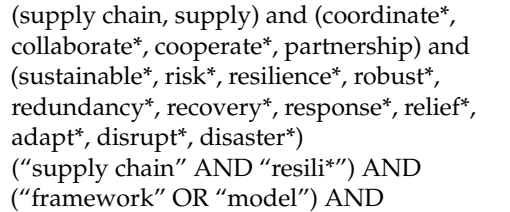 & Scopus and Web of Science library & $\checkmark$ & & $\checkmark$ & $\checkmark$ & $\checkmark$ & & $\checkmark$ & $\checkmark$ & & $\checkmark$ & & \\
\hline $\begin{array}{l}\text { This } \\
\text { paper }\end{array}$ & 2000-2020 & 232 & $\begin{array}{l}\text { ("performance" OR "measur" }{ }^{* \prime} \text { OR } \\
\text { "evaluat*" OR "management" OR } \\
\text { "assessment") }\end{array}$ & Scopus-ScienceDirect & & $\checkmark$ & $\checkmark$ & $\checkmark$ & $\checkmark$ & $\checkmark$ & $\checkmark$ & $\checkmark$ & $\checkmark$ & $\checkmark$ & $\checkmark$ & $\checkmark$ \\
\hline
\end{tabular}

CPE: Capabilities/principles/elements resilience; SR: Strategies to increase resilience; R: Risk; S: Stakeholders; PM: Performance measurement; PMS: Performance measurement system; SL: Strategic level; OL: Operational level; SUS: Sustainability; ECO: Economic; SOC: Social; ENV: Environmental 
Table A2. Resilience elements

\begin{tabular}{|c|c|c|c|c|}
\hline Elements & Description & $\begin{array}{l}\text { Articles That Consider the } \\
\text { Element in Your Model }\end{array}$ & $(\%)$ & References \\
\hline Flexibility & $\begin{array}{l}\text { The ability of the supply chain to adapt and deal with the } \\
\text { consequences of the disruptive event in the minimum } \\
\text { time and effort possible. Allows changing suppliers, } \\
\text { modifying the production process, worker } \\
\text { multifunctionality and replacement in the market. }\end{array}$ & 34 & $14.66 \%$ & $\begin{array}{l}{[1,2,12,25,29-33,37,114} \\
119,125,130,134,138 \\
139,157,160,163-168 \\
170,174,202,210-214]\end{array}$ \\
\hline Shared information & $\begin{array}{l}\text { The ability of the supply chain to have relevant, efficient } \\
\text { and timely information from all its members for joint } \\
\text { decision making. This information must include (among } \\
\text { others) density, complexity and criticality of the nodes in } \\
\text { the face of disruptive events. }\end{array}$ & 28 & $12.07 \%$ & $\begin{array}{l}{[25,26,29-33,46,114} \\
125,130,157,160,163 \\
165,168,169,190,202 \\
203,205,212-217]\end{array}$ \\
\hline Trust & $\begin{array}{l}\text { The belief of the supply chain members that their partners } \\
\text { in the chain are willing and able to fulfill their } \\
\text { responsibilities and make decisions of common benefit, } \\
\text { fulfilling the necessary actions before a disruptive event. }\end{array}$ & 25 & $10.77 \%$ & $\begin{array}{l}{[2,25,26,29,31-33,46,54} \\
114,128,130,157,163 \\
165,168,172,202,203 \\
205,212-214,217,218] \\
{[29-33,37,46,131,138}\end{array}$ \\
\hline Velocity & $\begin{array}{l}\text { The ability to respond rapidly to disruptive events by } \\
\text { efficiently distributing your critical resources. }\end{array}$ & 23 & $9.91 \%$ & $\begin{array}{l}{[29-33,3 /, 46,131,138} \\
157,163,166,167,174 \\
\text { 202,203,211,212,217, } \\
219-221]\end{array}$ \\
\hline Visibility & $\begin{array}{l}\text { The ability of the supply chain to know the identity, } \\
\text { location and status of its members in the face of any } \\
\text { disruption to the supply chain. }\end{array}$ & 22 & $9.48 \%$ & $\begin{array}{l}{[2,29-33,37,54,126,129} \\
131,136,157,163,168- \\
170,202,212,217]\end{array}$ \\
\hline Redundancy & $\begin{array}{l}\text { The ability to resist the disturbing event by designing and } \\
\text { managing security units or replacing critical nodes when a } \\
\text { disruptive event occurs. }\end{array}$ & 21 & $9.05 \%$ & $\begin{array}{l}{[29-33,37,46,119,132} \\
134,135,137,138,160 \\
163,165,167,202,214 \\
216,222]\end{array}$ \\
\hline Robustness & $\begin{array}{l}\text { The ability of the supply chain to maintain its functions } \\
\text { normally without disruption after the occurrence of a } \\
\text { disruptive event. }\end{array}$ & 21 & $9.05 \%$ & $\begin{array}{l}{[30-33,127,133-138} \\
163-167,197,214,216 \\
223,224]\end{array}$ \\
\hline Contingency planning & $\begin{array}{l}\text { The ability of the members of the supply chain to establish } \\
\text { and maintain coordinated work teams and defined } \\
\text { procedures for action in the face of possible disruptive } \\
\text { events caused by the environment and their } \\
\text { implementation when the event occurs. }\end{array}$ & 20 & $8.62 \%$ & $\begin{array}{l}{[2,12,19,32,33,37,46} \\
132,134,137,157,167- \\
170,185,213,214,222]\end{array}$ \\
\hline
\end{tabular}


Table A2. Cont.

\begin{tabular}{|c|c|c|c|c|}
\hline Elements & Description & $\begin{array}{l}\text { Articles That Consider the } \\
\text { Element in Your Model }\end{array}$ & $(\%)$ & References \\
\hline $\begin{array}{l}\text { Disruptive environment } \\
\text { awareness }\end{array}$ & $\begin{array}{l}\text { The ability of the supply chain to identify the existence of } \\
\text { possible disruptions and develop actions to avoid or } \\
\text { diminish their possible effects. }\end{array}$ & 16 & $6.89 \%$ & $\begin{array}{l}{[12,26,29,31,33,37,46,} \\
131,136,157,165,169, \\
170,172,218,225]\end{array}$ \\
\hline Knowledge Management & $\begin{array}{l}\text { The ability of the supply chain to analyze the } \\
\text { consequences of past disruptions and to establish learning } \\
\text { and action for the future based on them. It includes the } \\
\text { ability to manage its human resources to be trained, } \\
\text { coached and evaluated for performance in the face of } \\
\text { disruptive events. }\end{array}$ & 16 & $6.89 \%$ & $\begin{array}{l}{[26,31-33,37,46,129} \\
131,163,165,169,172 \\
213,218,225]\end{array}$ \\
\hline Market adaptation & $\begin{array}{l}\text { The ability of the supply chain to generate competitive } \\
\text { strategies according to the needs of the market (possibly } \\
\text { also affected by the disruption) that will allow it to recover } \\
\text { its previous share and situation or even improve it. }\end{array}$ & 10 & $4.31 \%$ & $\begin{array}{l}{[2,33,126,163,169,170,} \\
214,219,223,225]\end{array}$ \\
\hline Innovation & $\begin{array}{l}\text { The ability to create joint strategies to manage risk more } \\
\text { efficiently. Openness to learning and joint } \\
\text { decision making. }\end{array}$ & 2 & $0.86 \%$ & {$[25,33]$} \\
\hline Strategic alignment & $\begin{array}{l}\text { The ability of the system to define strategic goals of the } \\
\text { business and coordinate the implementation of actions in } \\
\text { all members of the supply chain. }\end{array}$ & 2 & $0.86 \%$ & {$[32,173]$} \\
\hline Leadership & $\begin{array}{l}\text { The ability to guide the establishment of risk mitigation } \\
\text { strategies, develop them and evaluate their benefits by } \\
\text { involving the necessary work teams of the organization. }\end{array}$ & 1 & $4.31 \%$ & [33] \\
\hline
\end{tabular}




\section{References}

1. Pereira, C.; Christopher, M.; Lago Da Silva, A. Achieving supply chain resilience: The role of procurement. Supply Chain Manag. An Int. J. 2014, 19, 626-642. [CrossRef]

2. Pettit, T.; Fiksel, J.; Croxton, K. Ensuring supply chain resilience: Development of a conceptual framework. J. Bus. Logist. 2010, 31, 1-21. [CrossRef]

3. Pettit, T.J.; Croxton, K.L.; Fiksel, J. Ensuring supply chain resilience: Development and implementation of an assessment tool. J. Bus. Logist. 2013, 34, 46-76. [CrossRef]

4. Ponis, S.; Koronis, E. Supply chain resilience: Definition of concept and its formative elements. J. Appl. Bus. Res. 2012, 28, 921-930. [CrossRef]

5. Seuring, S.; Müller, M. From a literature review to a conceptual framework for sustainable supply chain management. J. Clean. Prod. 2008, 16, 1699-1710. [CrossRef]

6. Qorri, A.; Mujkić, Z.; Kraslawski, A. A conceptual framework for measuring sustainability performance of supply chains. J. Clean. Prod. 2018, 189, 570-584. [CrossRef]

7. Verdecho, M.-J.; Alarcón-Valero, F.; Pérez-Perales, D.; Alfaro-Saiz, J.-J.; Rodríguez-Rodríguez, R. A methodology to select suppliers to increase sustainability within supply chains. Cent. Eur. J. Oper. Res. 2020, 1-21. [CrossRef]

8. Edgeman, R.; Wu, Z. Supply chain criticality in sustainable and resilient enterprises. J. Model. Manag. 2016, 11, 869-888. [CrossRef]

9. Marchese, D.; Reynolds, E.; Bates, M.E.; Morgan, H.; Clark, S.S.; Linkov, I. Resilience and sustainability: Similarities and differences in environmental management applications. Sci. Total Environ. 2018, 613-614, 1275-1283. [CrossRef]

10. Ahern, J. Urban landscape sustainability and resilience: The promise and challenges of integrating ecology with urban planning and design. Landsc. Ecol. 2013, 28, 1203-1212. [CrossRef]

11. Ramezankhani, M.; Torabi, S.; Vahidi, F. Supply chain performance measurement and evaluation: A mixed sustainability and resilience approach. Comput. Ind. Eng. 2018, 126, 531-548. [CrossRef]

12. Centobelli, P.; Cerchione, R.; Ertz, M. Managing supply chain resilience to pursue business and environmental strategies. Bus. Strateg. Environ. 2019. [CrossRef]

13. Ivanov, D. Revealing interfaces of supply chain resilience and sustainability: A simulation study. Int. J. Prod. Res. 2018, 56, 3507-3523. [CrossRef]

14. Fahimnia, B.; Jabbarzadeh, A. Marrying supply chain sustainability and resilience: A match made in heaven. Transp. Res. Part E Logist. Transp. Rev. 2016, 91, 306-324. [CrossRef]

15. Ruiz-Benitez, R.; López, C.; Real, J.C. Achieving sustainability through the lean and resilient management of the supply chain abstract. Int. J. Phys. Distrib. Logist. Manag. 2019, 49, 122-155. [CrossRef]

16. Pavlov, A.; Ivanov, D.; Pavlov, D.; Slinko, A. Optimization of network redundancy and contingency planning in sustainable and resilient supply chain resource management under conditions of structural dynamics. Ann. Oper. Res. 2019. [CrossRef]

17. Khot, S.B.; Thiagarajan, S. Resilience and sustainability of supply chain management in the Indian automobile industry. Int. J. Data Netw. Sci. 2019, 3, 339-348. [CrossRef]

18. Roostaie, S.; Nawari, N.; Kibert, C.J. Sustainability and resilience: A review of definitions, relationships, and their integration into a combined building assessment framework. Build. Environ. 2019, 154, 132-144. [CrossRef]

19. Davoudabadi, R.; Mousavi, S.M.; Sharifi, E. An integrated weighting and ranking model based on entropy, DEA and PCA considering two aggregation approaches for resilient supplier selection problem. J. Comput. Sci. 2020, 40. [CrossRef]

20. Carvalho, H.; Duarte, S.; Machado, V.C. Lean, agile, resilient and green: Divergencies and synergies. Int. J. Lean Six Sigma 2011, 2, 151-179. [CrossRef]

21. Wang, Z.; Zhang, J. Agent-based evaluation of humanitarian relief goods supply capability. Int. J. Disaster Risk Reduct. 2019, 36. [CrossRef]

22. Alikhani, R.; Torabi, S.A.; Altay, N. Strategic supplier selection under sustainability and risk criteria. Int. J. Prod. Econ. 2019, 208, 69-82. [CrossRef]

23. Zahiri, B.; Zhuang, J.; Mohammadi, M. Toward an integrated sustainable-resilient supply chain: A pharmaceutical case study. Transp. Res. Part E Logist. Transp. Rev. 2017, 103, 109-142. [CrossRef] 
24. Aboah, J.; Wilson, M.M.J.; Rich, K.M.; Lyne, M.C. Operationalising resilience in tropical agricultural value chains. Supply Chain Manag. 2019, 24, 271-300. [CrossRef]

25. Statsenko, L.; Corral de Zubielqui, G. Customer collaboration, service firms' diversification and innovation performance. Ind. Mark. Manag. 2019. [CrossRef]

26. Duong, L.N.K.; Chong, J. Supply chain collaboration in the presence of disruptions: A literature review. Int. J. Prod. Res. 2020, 1-20. [CrossRef]

27. Bhamra, R.; Dani, S.; Burnard, K. Resilience: The Concept, a Literature Review and Future Directions. Int. J. Prod. 2011, 49, 5375-5393. [CrossRef]

28. Heckmann, I.; Comes, T.; Nickel, S. A critical review on supply chain risk - Definition, measure and modeling. Omega 2015, 52, 119-132. [CrossRef]

29. Hohenstein, N.-O.; Feise, E.; Hartmann, E.; Giunipero, L. Research on the phenomenon of supply chain resilience: A systematic review and paths for further investigation. Int. J. Phys. Distrib. Logist. Manag. 2015, 45, 90-117. [CrossRef]

30. Kamalahmadi, M.; Parast, M. A review of the literature on the principles of enterprise and supply chain resilience: Major findings and directions for future research. Int. J. Prod. Econ. 2016, 171, 116-133. [CrossRef]

31. Ali, A.; Mahfouz, A.; Arisha, A. Analysing supply chain resilience: Integrating the constructs in a concept mapping framework via a systematic literature review. Supply Chain Manag. An Int. J. 2017, 22, 16-39. [CrossRef]

32. Umar, M.; Wilson, M.; Heyl, J. Food network resilience against natural disasters: A conceptual framework. SAGE Open 2017, 7, 3. [CrossRef]

33. Stone, J.; Rahimifard, S. Resilience in agri-food supply chains: A critical analysis of the literature and synthesis of a novel framework. Supply Chain Manag. An Int. J. 2018, 23, 207-238. [CrossRef]

34. Colicchia, C.; Creazza, A.; Noè, C.; Strozzi, F. Information sharing in supply chains: A review of risks and opportunities using the systematic literature network analysis (SLNA). Supply Chain Manag. 2019, 24, 5-21. [CrossRef]

35. Annarelli, A.; Nonino, F. Strategic and operational management of organizational resilience: Current state of research and future directions. Omega 2016, 62, 1-18. [CrossRef]

36. Behzadi, G.; O'Sullivan, M.; Olsen, T.; Zhang, A. Agribusiness supply chain risk management: A review of quantitative decision models. Omega 2018, 79, 21-42. [CrossRef]

37. Kochan, C.; Nowicki, D. Supply chain resilience: A systematic literature review and typological framework. Int. J. Phys. Distrib. Logist. Manag. 2018, 48, 842-865. [CrossRef]

38. Hosseini, S.; Ivanov, D.; Dolgui, A. Review of quantitative methods for supply chain resilience analysis. Transp. Res. Part E Logist. Transp. Rev. 2019, 125, 285-307. [CrossRef]

39. Tranfield, D.; Denyer, D.; Smart, P. Towards a methodology for developing evidence-informed management knowledge by means of systematic review. Br. J. Manag. 2003, 14, 207-222. [CrossRef]

40. Denyer, D.; Tranfield, D. Producing a systematic review. In The Sage handbook of organizational research methods; SAGE Publications Ltd.: Southend Oaks, CA, USA, 2009; pp. 671-689. ISBN 978-1-4129-3118-2.

41. Rousseau, D.; Manning, J.; Denyer, D. Evidence in Management and Organizational Science: Assembling the Field's Full Weight of Scientific Knowledge Through Syntheses. Acad. Manag. Ann. 2008, 2, 475-515. [CrossRef]

42. Zimmer, K.; Fröhling, M.; Schultmann, F. Sustainable supplier management - a review of models supporting sustainable supplier selection, monitoring and development. Int. J. Prod. Res. 2016, 54, 1412-1442. [CrossRef]

43. Natarajarathinam, M.; Capar, I.; Narayanan, A. Managing supply chains in times of crisis: A review of literature and insights. Int. J. Phys. Distrib. Logist. Manag. 2009, 39, 535-573. [CrossRef]

44. Tang, C.; Tomlin, B. The power of flexibility for mitigating supply chain risks. Int. J. Prod. Econ. 2008, 116, 12-27. [CrossRef]

45. Kleindorfer, P.; Saad, G. Managing disruption risks in supply chains. Prod. Oper. Manag. 2005, 14, 53-68. [CrossRef]

46. Christopher, M.; Peck, H. Building the Resilient Supply Chain. Int. J. Logist. Manag. 2004, 15, 1-14. [CrossRef]

47. Wu, T.; Huang, S.; Blackhurst, J.; Zhang, X.; Wang, S. Supply chain risk management: An agent-based simulation to study the impact of retail stockouts. IEEE Trans. Eng. Manag. 2013, 60, 676-686. [CrossRef]

48. Fang, H.; Xiao, R. Resilient closed-loop supply chain network design based on patent protection. Int. J. Comput. Appl. Technol. 2013, 48, 49-57. [CrossRef] 
49. Gong, J.; Mitchell, J.E.; Krishnamurthy, A.; Wallace, W.A. An interdependent layered network model for a resilient supply chain. Omega 2014, 46, 104-116. [CrossRef]

50. Mari, S.; Lee, Y.; Memon, M. Sustainable and resilient supply chain network design under disruption risks. Sustainability 2014, 6, 6666-6686. [CrossRef]

51. Bueno-Solano, A.; Cedillo-Campos, M. Dynamic impact on global supply chains performance of disruptions propagation produced by terrorist acts. Transp. Res. Part E Logist. Transp. Rev. 2014, 61, 1-12. [CrossRef]

52. Costantino, F.; Di Gravio, G.; Shaban, A.; Tronci, M. Replenishment policy based on information sharing to mitigate the severity of supply chain disruption. Int. J. Logist. Syst. Manag. 2014, 18, 3-23. [CrossRef]

53. Kristianto, Y.; Gunasekaran, A.; Helo, P.; Hao, Y. A model of resilient supply chain network design: A two-stage programming with fuzzy shortest path. Expert Syst. Appl. 2014, 41, 39-49. [CrossRef]

54. Raj, R.; Wang, J.; Nayak, A.; Tiwari, M.; Han, B.; Liu, C.; Zhang, W. Measuring the resilience of supply chain systems using a survival model. IEEE Syst. J. 2015, 9, 377-381. [CrossRef]

55. Loh, H.S.; Thai, V. V Cost Consequences of a Port-Related Supply Chain Disruption. Asian J. Shipp. Logist. 2015, 31, 319-340. [CrossRef]

56. Torabi, S.; Baghersad, M.; Mansouri, S. Resilient supplier selection and order allocation under operational and disruption risks. Transp. Res. Part E Logist. Transp. Rev. 2015, 79, 22-48. [CrossRef]

57. Wicher, P.; Staš, D.; Karkula, M.; Lenort, R.; Besta, P. A computer simulation-based analysis of supply chains resilience in industrial environment. Metalurgija 2015, 54, 703-706.

58. Cardoso, S.R.; Paula Barbosa-Póvoa, A.; Relvas, S.; Novais, A.Q. Resilience metrics in the assessment of complex supply-chains performance operating under demand uncertainty. Omega 2015, 56, 53-73. [CrossRef]

59. Salehi, N.; Torabi, S.A.; Sahebjamnia, N. Retail supply chain network design under operational and disruption risks. Transp. Res. Part E Logist. Transp. Rev. 2015, 75, 95-114. [CrossRef]

60. Dixit, V.; Seshadrinath, N.; Tiwari, M.K. Performance measures based optimization of supply chain network resilience: A NSGA-II + Co-Kriging approach. Comput. Ind. Eng. 2016, 93, 205-214. [CrossRef]

61. Liu, F.; Song, J.-S.; Tong, J.D. Building Supply Chain Resilience through Virtual Stockpile Pooling. Prod. Oper. Manag. 2016, 25, 1745-1762. [CrossRef]

62. Fahimnia, B.; Jabbarzadeh, A.; Sarkis, J. Greening versus resilience: A supply chain design perspective. Transp. Res. Part E Logist. Transp. Rev. 2018, 119, 129-148. [CrossRef]

63. Hasani, A.; Khosrojerdi, A. Robust global supply chain network design under disruption and uncertainty considering resilience strategies: A parallel memetic algorithm for a real-life case study. Transp. Res. Part E Logist. Transp. Rev. 2016, 87, 20-52. [CrossRef]

64. Azhmyakov, V.; Fernández-Gutiérrez, J.P.; Gadi, S.K.; Pickl, S. A Novel Numerical Approach to the MCLP Based Resilent Supply Chain Optimization. IFAC-PapersOnLine 2016, 49, 137-142. [CrossRef]

65. Ivanov, D.; Sokolov, B.; Solovyeva, I.; Dolgui, A.; Jie, F. Dynamic recovery policies for time-critical supply chains under conditions of ripple effect. Int. J. Prod. Res. 2016, 54, 7245-7258. [CrossRef]

66. Jabbarzadeh, A.; Fahimnia, B.; Sheu, J.-B.; Moghadam, H.S. Designing a supply chain resilient to major disruptions and supply/demand interruptions. Transp. Res. Part B Methodol. 2016, 94, 121-149. [CrossRef]

67. Babich, V.; Ritchken, P.H. Competition and Diversification Effects in Supply Chains with Supplier Default Risk. Manuf. Serv. Oper. Manag. 2007, 9, 123-146. [CrossRef]

68. Bogataj, D.; Aver, B.; Bogataj, M. Supply chain risk at simultaneous robust perturbations. Int. J. Prod. Econ. 2016, 181, 68-78. [CrossRef]

69. Wang, X.; Herty, M.; Zhao, L. Contingent rerouting for enhancing supply chain resilience from supplier behavior perspective. Int. Trans. Oper. Res. 2016, 23, 775-796. [CrossRef]

70. Zeng, B.; Yen, B.P.-C. Rethinking the role of partnerships in global supply chains: A risk-based perspective. Int. J. Prod. Econ. 2017, 185, 52-62. [CrossRef]

71. Lücker, F.; Seifert, R.W. Building up Resilience in a Pharmaceutical Supply Chain through Inventory, Dual Sourcing and Agility Capacity. Omega 2017, 73, 114-124. [CrossRef]

72. Fattahi, M.; Govindan, K.; Keyvanshokooh, E. Responsive and resilient supply chain network design under operational and disruption risks with delivery lead-time sensitive customers. Transp. Res. Part E Logist. Transp. Rev. 2017, 101, 176-200. [CrossRef]

73. Kırılmaz, O.; Erol, S. A proactive approach to supply chain risk management: Shifting orders among suppliers to mitigate the supply side risks. J. Purch. Supply Manag. 2017, 23, 54-65. [CrossRef] 
74. Li, H.; Pedrielli, G.; Lee, L.; Chew, E. Enhancement of supply chain resilience through inter-echelon information sharing. Flex. Serv. Manuf. J. 2017, 29, 260-285. [CrossRef]

75. Otto, C.; Willner, S.; Wenz, L.; Frieler, K.; Levermann, A. Modeling loss-propagation in the global supply network: The dynamic agent-based model acclimate. J. Econ. Dyn. Control 2017, 83, 232-269. [CrossRef]

76. Rezapour, S.; Farahani, R.Z.; Pourakbar, M. Resilient supply chain network design under competition: A case study. Eur. J. Oper. Res. 2017, 259, 1017-1035. [CrossRef]

77. Ledwoch, A.; Yasarcan, H.; Brintrup, A. The moderating impact of supply network topology on the effectiveness of risk management. Int. J. Prod. Econ. 2018, 197, 13-26. [CrossRef]

78. Al-Othman, W.B.E.; Lababidi, H.M.S.; Alatiqi, I.M.; Al-Shayji, K. Supply chain optimization of petroleum organization under uncertainty in market demands and prices. Eur. J. Oper. Res. 2008, 189, 822-840. [CrossRef]

79. Ivanov, D.; Dolgui, A.; Sokolov, B. Scheduling of recovery actions in the supply chain with resilience analysis considerations. Int. J. Prod. Res. 2018, 56, 6473-6490. [CrossRef]

80. Das, K. Integrating lean, green, and resilience criteria in a sustainable food supply chain planning model. Int. J. Math. Eng. Manag. Sci. 2019, 4, 259-275. [CrossRef]

81. Das, K. Integrating resilience in a supply chain planning model. Int. J. Qual. Reliab. Manag. 2018, 35, 570-595. [CrossRef]

82. Arora, V.; Ventresca, M. Modeling topologically resilient supply chain networks. Appl. Netw. Sci. 2018, 3, 19. [CrossRef]

83. Almeida, J.F.D.F.; Conceição, S.V.; Pinto, L.R.; De Camargo, R.S.; De Miranda, G., Jr. Flexibility evaluation of multiechelon supply chains. PLoS ONE 2018, 13, e0194050. [CrossRef] [PubMed]

84. Mancheri, N.; Sprecher, B.; Deetman, S.; Young, S.; Bleischwitz, R.; Dong, L.; Kleijn, R.; Tukker, A. Resilience in the tantalum supply chain. Resour. Conserv. Recycl. 2018, 129, 56-69. [CrossRef]

85. Namdar, J.; Li, X.; Sawhney, R.; Pradhan, N. Supply chain resilience for single and multiple sourcing in the presence of disruption risks. Int. J. Prod. Res. 2018, 56, 2339-2360. [CrossRef]

86. Rozhkov, M.; Ivanov, D. Contingency production-inventory control policy for capacity disruptions in the retail supply chain with perishable products. IFAC-PapersOnLine 2018, 51, 1448-1452. [CrossRef]

87. Sabouhi, F.; Pishvaee, M.; Jabalameli, M. Resilient supply chain design under operational and disruption risks considering quantity discount: A case study of pharmaceutical supply chain. Comput. Ind. Eng. 2018, 126, 657-672. [CrossRef]

88. Zavitsas, K.; Zis, T.; Bell, M.G.H. The impact of flexible environmental policy on maritime supply chain resilience. Transp. Policy 2018, 72, 116-128. [CrossRef]

89. Mitra, K.; Gudi, R.; Patwardhan, S.; Sardar, G. Towards resilient supply chains: Uncertainty analysis using fuzzy mathematical programming. Chem. Eng. Res. Des. 2009, 87, 967-981. [CrossRef]

90. Lücker, F.; Seifert, R.W.; Biçer, I. Roles of inventory and reserve capacity in mitigating supply chain disruption risk. Int. J. Prod. Res. 2019, 57, 1238-1249. [CrossRef]

91. Diabat, A.; Jabbarzadeh, A.; Khosrojerdi, A. A perishable product supply chain network design problem with reliability and disruption considerations. Int. J. Prod. Econ. 2019, 212, 125-138. [CrossRef]

92. Jabbarzadeh, A.; Fahimnia, B.; Rastegar, S. Green and Resilient Design of Electricity Supply Chain Networks: A Multiobjective Robust Optimization Approach. IEEE Trans. Eng. Manag. 2019, 66, 52-72. [CrossRef]

93. Habib, M.S.; Sarkar, B.; Tayyab, M.; Saleem, M.W.; Hussain, A.; Ullah, M.; Omair, M.; Iqbal, M.W. Large-scale disaster waste management under uncertain environment. J. Clean. Prod. 2019, 212, 200-222. [CrossRef]

94. Hosnavi, R.; Nekooie, M.A.; Khalili, S.M.; Tavakoli, A. A resilient supply portfolio considering political and disruption risks. Int. J. Ind. Syst. Eng. 2019, 31, 209-249. [CrossRef]

95. Ivanov, D.; Dolgui, A.; Sokolov, B. The impact of digital technology and Industry 4.0 on the ripple effect and supply chain risk analytics. Int. J. Prod. Res. 2019, 57, 829-846. [CrossRef]

96. Zhao, S.; You, F. Resilient supply chain design and operations with decision-dependent uncertainty using a data-driven robust optimization approach. AIChE J. 2019, 65, 1006-1021. [CrossRef]

97. Kwesi-Buor, J.; Menachof, D.; Talas, R. Scenario analysis and disaster preparedness for port and maritime logistics risk management. Accid. Anal. Prev. 2019, 123, 433-447. [CrossRef]

98. Mikhail, M.; El-Beheiry, M.; Afia, N. Incorporating resilience determinants in supply chain network design model. J. Model. Manag. 2019. [CrossRef] 
99. Mohammed, A.; Harris, I.; Soroka, A.; Nujoom, R. A hybrid MCDM-fuzzy multi-objective programming approach for a G-resilient supply chain network design. Comput. Ind. Eng. 2019, 127, 297-312. [CrossRef]

100. Briano, E.; Caballini, C.; Giribone, P.; Revetria, R. Resiliency and vulnerability in short life cycle products' supply chains: A system dynamics model. WSEAS Trans. Syst. 2010, 9, 327-337.

101. Hosseini, S.; Morshedlou, N.; Ivanov, D.; Sarder, M.D.; Barker, K.; Khaled, A.A. Resilient supplier selection and optimal order allocation under disruption risks. Int. J. Prod. Econ. 2019, 213, 124-137. [CrossRef]

102. Thekdi, S.; Santos, J. Decision-Making Analytics Using Plural Resilience Parameters for Adaptive Management of Complex Systems. Risk Anal. 2019, 39, 871-889. [CrossRef]

103. Yavari, M.; Zaker, H. An integrated two-layer network model for designing a resilient green-closed loop supply chain of perishable products under disruption. J. Clean. Prod. 2019, 230, 198-218. [CrossRef]

104. Cavalcante, I.M.; Frazzon, E.M.; Forcellini, F.A.; Ivanov, D. A supervised machine learning approach to data-driven simulation of resilient supplier selection in digital manufacturing. Int. J. Inf. Manag. 2019, 49, 86-97. [CrossRef]

105. Fang, H.; Li, C.; Xiao, R. Supply chain network design based on brand differentiation and resilient management. J. Inf. Comput. Sci. 2012, 9, 3977-3986.

106. Schmitt, A.; Singh, M. A quantitative analysis of disruption risk in a multi-echelon supply chain. Int. J. Prod. Econ. 2012, 139, 22-32. [CrossRef]

107. Zhu, J.; Ruth, M. Exploring the resilience of industrial ecosystems. J. Environ. Manag. 2013, 122, 65-75. [CrossRef]

108. Venkatesan, S.P.; Kumanan, S. Supply chain risk prioritisation using a hybrid AHP and PROMETHEE approach. Int. J. Serv. Oper. Manag. 2012, 13, 19-41. [CrossRef]

109. Valipour Parkouhi, S.; Safaei Ghadikolaei, A. A resilience approach for supplier selection: Using Fuzzy Analytic Network Process and grey VIKOR techniques. J. Clean. Prod. 2017, 161, 431-451. [CrossRef]

110. Jain, V.; Kumar, S.; Soni, U.; Chandra, C. Supply chain resilience: Model development and empirical analysis. Int. J. Prod. Res. 2017, 55, 6779-6800. [CrossRef]

111. Malek, A.; Ebrahimnejad, S.; Tavakkoli-Moghaddam, R. An improved hybrid grey relational analysis approach for green resilient supply chain network assessment. Sustainability 2017, 9, 1433. [CrossRef]

112. Mital, M.; Del Giudice, M.; Papa, A. Comparing supply chain risks for multiple product categories with cognitive mapping and Analytic Hierarchy Process. Technol. Forecast. Soc. Change 2018, 131, 159-170. [CrossRef]

113. Ruiz-Benítez, R.; López, C.; Real, J.C. The lean and resilient management of the supply chain and its impact on performance. Int. J. Prod. Econ. 2018, 203, 190-202. [CrossRef]

114. Sharma, S.K.; George, S.A. Modelling resilience of truckload transportation industry. Benchmarking 2018, 25, 2531-2545. [CrossRef]

115. Costa, A.S.; Govindan, K.; Figueira, J.R. Supplier classification in emerging economies using the ELECTRE TRI-nC method: A case study considering sustainability aspects. J. Clean. Prod. 2018, 201, 925-947. [CrossRef]

116. Aggarwal, S.; Srivastava, M.K. A grey-based DEMATEL model for building collaborative resilience in supply chain. Int. J. Qual. Reliab. Manag. 2019, 36, 8, 1409-1437. [CrossRef]

117. Pashapour, S.; Bozorgi-Amiri, A.; Azadeh, A.; Ghaderi, S.F.; Keramati, A. Performance optimization of organizations considering economic resilience factors under uncertainty: A case study of a petrochemical plant. J. Clean. Prod. 2019, 231, 1526-1541. [CrossRef]

118. Hosseini, S.; Ivanov, D. A new resilience measure for supply networks with the ripple effect considerations: A Bayesian network approach. Ann. Oper. Res. 2019, 1-27. [CrossRef]

119. Govindan, K.; Azevedo, S.G.; Carvalho, H.; Cruz-Machado, V. Lean, green and resilient practices influence on supply chain performance: Interpretive structural modeling approach. Int. J. Environ. Sci. Technol. 2015, 12, 15-34. [CrossRef]

120. Hosseini, S.; Khaled, A.A. A hybrid ensemble and AHP approach for resilient supplier selection. J. Intell. Manuf. 2019, 30, 207-228. [CrossRef]

121. Zanjirani, D.; Hashemkhani Zolfani, S.; Prentkovskis, O. L.A.R.G. supplier selection based on integrating house of quality, Taguchi loss function and M.O.P.A. Econ. Res. Istraz. 2019, 32, 1944-1964. [CrossRef]

122. Davoudabadi, R.; Mousavi, S.M.; Mohagheghi, V.; Vahdani, B. Resilient Supplier Selection Through Introducing a New Interval-Valued Intuitionistic Fuzzy Evaluation and Decision-Making Framework. Arab. J. Sci. Eng. 2019, 44, 7351-7360. [CrossRef] 
123. Dubey, R.; Gunasekaran, A.; Childe, S.J.; Papadopoulos, T.; Blome, C.; Luo, Z. Antecedents of Resilient Supply Chains: An Empirical Study. IEEE Trans. Eng. Manag. 2019, 66, 8-19. [CrossRef]

124. Meuwissen, M.P.M.; Feindt, P.H.; Spiegel, A.; Termeer, C.J.A.M.; Mathijs, E.; de Mey, Y.; Finger, R.; Balmann, A.; Wauters, E.; Urquhart, J.; et al. A framework to assess the resilience of farming systems. Agric. Syst. 2019, 176, 102656. [CrossRef]

125. Abeysekara, N.; Wang, H.; Kuruppuarachchi, D. Effect of supply-chain resilience on firm performance and competitive advantage: A study of the Sri Lankan apparel industry. Bus. Process Manag. J. 2019, 25, 1673-1695. [CrossRef]

126. Bevilacqua, M.; Ciarapica, F.E.; Marcucci, G.; Mazzuto, G. Fuzzy cognitive maps approach for analysing the domino effect of factors affecting supply chain resilience: A fashion industry case study. Int. J. Prod. Res. 2019, 1-29. [CrossRef]

127. Wang, W.; Huang, L.; Zhu, Y.; Jiang, L.; Sahu, A.K.; Sahu, A.K.; Sahu, N.K. Decision support system toward evaluation of resilient supplier: A novel fuzzy gain-loss computational approach. Kybernetes 2019, 49, 6, 1741-1765. [CrossRef]

128. Jafarnejad, A.; Momeni, M.; Razavi Hajiagha, S.H.; Faridi Khorshidi, M. A dynamic supply chain resilience model for medical equipment's industry. J. Model. Manag. 2019, 14, 816-840. [CrossRef]

129. Kumar, S.; Anbanandam, R. An integrated Delphi - fuzzy logic approach for measuring supply chain resilience: An illustrative case from manufacturing industry. Meas. Bus. Excell. 2019, 23, 350-375. [CrossRef]

130. Aigbogun, O.; Ghazali, Z.; Razali, R. The mediating impact of Halal logistics on supply chain resilience: An agency perspective. Int. Rev. Manag. Mark. 2016, 6, 209-216.

131. Kumar, S.; Anbanandam, R. Impact of risk management culture on supply chain resilience: An empirical study from Indian manufacturing industry. Proc. Inst. Mech. Eng. Part O J. Risk Reliab. 2019, 234, 246-259. [CrossRef]

132. Shao, L.; Jin, S. Resilience assessment of the lithium supply chain in China under impact of new energy vehicles and supply interruption. J. Clean. Prod. 2020, 252, 119624. [CrossRef]

133. Junaid, M.; Xue, Y.; Syed, M.W.; Li, J.Z.; Ziaullah, M. A neutrosophic ahp and topsis framework for supply chain risk assessment in automotive industry of Pakistan. Sustainability 2020, 12, 154. [CrossRef]

134. Mohammed, A. Towards 'gresilient' supply chain management: A quantitative study. Resour. Conserv. Recycl. 2020, 155, 104641. [CrossRef]

135. Nguyen, H.; Sharkey, T.C.; Wheeler, S.; Mitchell, J.E.; Wallace, W.A. Towards the development of quantitative resilience indices for Multi-Echelon Assembly Supply Chains. Omega 2020, 102199. [CrossRef]

136. Rajesh, R. A grey-layered ANP based decision support model for analyzing strategies of resilience in electronic supply chains. Eng. Appl. Artif. Intell. 2020, 87, 103338. [CrossRef]

137. Hosseini, S.; Barker, K. A Bayesian network model for resilience-based supplier selection. Int. J. Prod. Econ. 2016, 180, 68-87. [CrossRef]

138. Sahu, A.; Datta, S.; Mahapatra, S. Evaluation and selection of resilient suppliers in fuzzy environment: Exploration of fuzzy-VIKOR. Benchmarking 2016, 23, 651-673. [CrossRef]

139. Wicher, P.; Zapletal, F.; Lenort, R.; Staš, D. Measuring the metallurgical supply chain resilience using fuzzy analytic network process. Metalurgija 2016, 55, 783-786.

140. Mari, I.; Lee, H.; Memon, S. Sustainable and Resilient Garment Supply Chain Network Design with Fuzzy Multi-Objectives under Uncertainty. Sustainability 2016, 8, 1038. [CrossRef]

141. Rajesh, R.; Ravi, V. Analyzing drivers of risks in electronic supply chains: A grey-DEMATEL approach. Int. J. Adv. Manuf. Technol. 2017, 94, 1127-1145. [CrossRef]

142. Wang, T.-K.; Zhang, Q.; Chong, H.-Y.; Wang, X. Integrated supplier selection framework in a resilient construction supply chain: An approach via analytic hierarchy process (AHP) and grey relational analysis (GRA). Sustainability 2017, 9, 289. [CrossRef]

143. Rajesh, R. A fuzzy approach to analyzing the level of resilience in manufacturing supply chains. Sustain. Prod. Consum. 2019, 18, 224-236. [CrossRef]

144. Aviso, K.B.; Mayol, A.P.; Promentilla, M.A.B.; Santos, J.R.; Tan, R.R.; Ubando, A.T.; Yu, K.D.S. Allocating human resources in organizations operating under crisis conditions: A fuzzy input-output optimization modeling framework. Resour. Conserv. Recycl. 2018, 128, 250-258. [CrossRef]

145. Sen, D.; Datta, S.; Mahapatra, S. On evaluation of supply chain's ecosilient (g-resilient) performance index: A fuzzy embedded decision support framework. Benchmarking 2018, 25, 2370-2389. [CrossRef] 
146. Wang, J.; Wu, Y. An improved Voronoi-diagram-based algorithm for continuous facility location problem under disruptions. Sustainability 2018, 10, 3099. [CrossRef]

147. Pavlov, A.; Ivanov, D.; Dolgui, A.; Sokolov, B. Hybrid Fuzzy-Probabilistic Approach to Supply Chain Resilience Assessment. IEEE Trans. Eng. Manag. 2018, 65, 303-315. [CrossRef]

148. Bottani, E.; Murino, T.; Schiavo, M.; Akkerman, R. Resilient food supply chain design: Modelling framework and metaheuristic solution approach. Comput. Ind. Eng. 2019, 135, 177-198. [CrossRef]

149. Dormady, N.; Roa-Henriquez, A.; Rose, A. Economic resilience of the firm: A production theory approach. Int. J. Prod. Econ. 2019, 208, 446-460. [CrossRef]

150. Rajesh, R. Network design for resilience in supply chains using novel crazy elitist TLBO. Neural Comput. Appl. 2019. [CrossRef]

151. Tan, R.R.; Aviso, K.B.; Cayamanda, C.D.; Chiu, A.S.F.; Promentilla, M.A.B.; Ubando, A.T.; Yu, K.D.S. A fuzzy linear programming enterprise input-output model for optimal crisis operations in industrial complexes. Int. J. Prod. Econ. 2016, 181, 410-418. [CrossRef]

152. Chang, K.-H.; Cheng, C.-R. Application of intuitionistic fuzzy entropy to disruption risk management in aerospace supply chain. Appl. Math. Inf. Sci. 2016, 10, 1035-1046. [CrossRef]

153. Pournader, M.; Rotaru, K.; Kach, A.P.; Razavi Hajiagha, S.H. An analytical model for system-wide and tier-specific assessment of resilience to supply chain risks. Supply Chain Manag. 2016, 21, 589-609. [CrossRef]

154. Rajesh, R. Forecasting supply chain resilience performance using grey prediction. Electron. Commer. Res. Appl. 2016, 20, 42-58. [CrossRef]

155. Sahu, A.; Datta, S.; Mahapatra, S. Evaluation of performance index in resilient supply chain: A fuzzy-based approach. Benchmarking An Int. J. 2017, 24, 118-142. [CrossRef]

156. Brosas, M.E.; Kilantang, M.A.; Li, N.B.; Ocampo, L.; Promentilla, M.A.; Yu, K.D. Novel approach for manufacturing supply chain risk analysis using fuzzy supply inoperability input-output model. Manuf. Lett. 2017, 12, 1-5. [CrossRef]

157. Alimohammadlou, M.; Bonyani, A. An integrated fuzzy model for resilient supplier selection. Int. J. Supply Chain Manag. 2018, 7, 35-52.

158. Chowdhury, M.M.H.; Quaddus, M. Supply chain readiness, response and recovery for resilience. Supply Chain Manag. 2016, 21, 709-731. [CrossRef]

159. Chopra, S.; Meindl, P. Administración de la Cadena de Suministro. Estrategia, planeación y operación., 5th ed.; Pearson Education: México City, México, 2013; ISBN 9786073221337.

160. Ponomarov, S.Y.; Holcomb, M.C. Understanding the concept of supply chain resilience. Int. J. Logist. Manag. 2009, 20, 124-143. [CrossRef]

161. Colicchia, C.; Dallari, F.; Melacini, M. Increasing supply chain resilience in a global sourcing context. Prod. Plan. Control 2010, 21, 680-694. [CrossRef]

162. Blackhurst, J.; Dunn, K.S.; Craighead, C.W. An empirically derived framework of global supply resiliency. J. Bus. Logist. 2011, 32, 374-391. [CrossRef]

163. Singh, C.; Soni, G.; Badhotiya, G. Performance indicators for supply chain resilience: Review and conceptual framework. J. Ind. Eng. Int. 2019, 15, 105-117. [CrossRef]

164. Rashid, A.H.; Loke, S.-P.; Ooi, K.-B. Strengthening supply chain risk management for business continuity: A case study approach. Int. J. Manag. Enterp. Dev. 2014, 13, 278-301. [CrossRef]

165. Scholten, K.; Scott, P.S.; Fynes, B. Mitigation processes - antecedents for building supply chain resilience. Supply Chain Manag. 2014, 19, 211-228. [CrossRef]

166. Purvis, L.; Spall, S.; Naim, M.; Spiegler, V. Developing a resilient supply chain strategy during 'boom' and 'bust'. Prod. Plan. Control 2016, 27, 579-590. [CrossRef]

167. Hosseini, S.; Al Khaled, A.; Sarder, M. A general framework for assessing system resilience using Bayesian networks: A case study of sulfuric acid manufacturer. J. Manuf. Syst. 2016, 41, 211-227. [CrossRef]

168. Alvarenga, M.Z.; de Oliveira, M.P.V.; Filho, H.Z.; dos Santos, W.R. Analytical supply chains: Are they more resilient? A model's proposition. J. Oper. Supply Chain Manag. 2018, 11, 46-58. [CrossRef]

169. Soni, U.; Jain, V.; Kumar, S. Measuring supply chain resilience using a deterministic modeling approach. Comput. Ind. Eng. 2014, 74, 11-25. [CrossRef]

170. Zainal Abidin, N.A.; Ingirige, B. The dynamics of vulnerabilities and capabilities in improving resilience within Malaysian construction supply chain. Constr. Innov. 2018, 18, 412-432. [CrossRef] 
171. Mandal, S. An empirical competence-capability model of supply chain resilience. Int. J. Disaster Resil. Built Environ. 2017, 8. [CrossRef]

172. Mandal, S. The influence of organizational culture on healthcare supply chain resilience: Moderating role of technology orientation. J. Bus. Ind. Mark. 2017, 32, 1021-1037. [CrossRef]

173. Chowdhury, M.; Quaddus, M. Supply chain resilience: Conceptualization and scale development using dynamic capability theory. Int. J. Prod. Econ. 2017, 188, 185-204. [CrossRef]

174. Carvalho, H.; Azevedo, S.G.; Cruz-Machado, V. Agile and resilient approaches to supply chain management: Influence on performance and competitiveness. Logist. Res. 2012, 4, 49-62. [CrossRef]

175. Kwak, D.-W.; Seo, Y.-J.; Mason, R. Investigating the relationship between supply chain innovation, risk management capabilities and competitive advantage in global supply chains. Int. J. Oper. Prod. Manag. 2018, 38, 2-21. [CrossRef]

176. Hollnagel, E. Epilogue: RAG: The resilience analysis Grid. In Resilience Engineering in Practice: A guidebook; Hollnagel, E., Paries, J., Woods, D., Wreathall, J., Eds.; Ashgate Publishing: Farnham, England, 2011; pp. 275-296.

177. Vroegindewey, R.; Hodbod, J. Resilience of Agricultural Value Chains in Developing Country Contexts: A Framework and Assessment Approach. Sustainability 2018, 10, 916. [CrossRef]

178. Jüttner, U.; Peck, H.; Christopher, M. Supply chain risk management: Outlining an agenda for future research. Int. J. Logist. Res. Appl. 2003, 6, 197-210. [CrossRef]

179. Sáenz, M.J.; Revilla, E.; Acero, B. Aligning supply chain design for boosting resilience. Bus. Horiz. 2018, 61, 443-452. [CrossRef]

180. Harland, C.; Brenchley, R.; Walker, H. Risk in supply networks. J. Purch. Supply Manag. 2003, 9, 51-62. [CrossRef]

181. Briano, E.; Caballini, C.; Giribone, P.; Revetria, R. Objectives and perspectives for improving resiliency in supply chains. WSEAS Trans. Syst. 2010, 9, 136-145.

182. Ho, W.; Zheng, T.; Yildiz, H.; Talluri, S. Supply chain risk management: A literature review. Int. J. Prod. Res. 2015, 53, 5031-5069. [CrossRef]

183. Collier, Z.; Connelly, E.; Polmateer, T.; Lambert, J. Value chain for next-generation biofuels: Resilience and sustainability of the product life cycle. Environ. Syst. Decis. 2017, 37, 22-33. [CrossRef]

184. de Souza, V.; Bloemhof-Ruwaard, J.; Borsato, M. Towards Regenerative Supply Networks: A design framework proposal. J. Clean. Prod. 2019, 221, 145-156. [CrossRef]

185. Kaur, H.; Singh, S.P.; Garza-Reyes, J.A.; Mishra, N. Sustainable stochastic production and procurement problem for resilient supply chain. Comput. Ind. Eng. 2020, 139, 105560. [CrossRef]

186. Hosseini-Motlagh, S.-M.; Samani, M.R.G.; Saadi, F.A. A novel hybrid approach for synchronized development of sustainability and resiliency in the wheat network. Comput. Electron. Agric. 2020, 168, 105095. [CrossRef]

187. Ramirez-Peña, M.; Sánchez Sotano, A.J.; Pérez-Fernandez, V.; Abad, F.J.; Batista, M. Achieving a sustainable shipbuilding supply chain under I4.0 perspective. J. Clean. Prod. 2020, 244, 118789. [CrossRef]

188. Bai, C.; Sarkis, J. Green supplier development: Analytical evaluation using rough set theory. J. Clean. Prod. 2010, 18, 1200-1210. [CrossRef]

189. Valipour Parkouhi, S.; Safaei Ghadikolaei, A.; Fallah Lajimi, H. Resilient supplier selection and segmentation in grey environment. J. Clean. Prod. 2019, 207, 1123-1137. [CrossRef]

190. Mandal, S.; Bhattacharya, S.; Korasiga, V.; Sarathy, R. The dominant influence of logistics capabilities on integration: Empirical evidence from supply chain resilience. Int. J. Disaster Resil. Built Environ. 2017, 8, 357-374. [CrossRef]

191. Elluru, S.; Gupta, H.; Kaur, H.; Singh, S.P. Proactive and reactive models for disaster resilient supply chain. Ann. Oper. Res. 2019, 283, 199-224. [CrossRef]

192. Alfaro, J.; Ortiz, Á.; Rodríguez, R. Performance measurement system for enterprise networks. Int. J. Product. Perform. Manag. 2007, 56, 305-334. [CrossRef]

193. Bititci, U.; Mendibil, K.; Martinez, V.; Albores, P. Measuring and managing performance in extended enterprises. Int. J. Oper. Prod. Manag. 2005, 25, 333-353. [CrossRef]

194. Ali, I.; Nagalingam, S.; Gurd, B. Building resilience in SMEs of perishable product supply chains: Enablers, barriers and risks. Prod. Plan. Control 2017, 28, 1236-1250. [CrossRef]

195. Dolgui, A.; Ivanov, D.; Sokolov, B. Ripple effect in the supply chain: An analysis and recent literature. Int. J. Prod. Res. 2018, 56, 414-430. [CrossRef] 
196. Alotaibi, Y. Business process modelling challenges and solutions: A literature review. J. Intell. Manuf. 2016, 27, 701-723. [CrossRef]

197. Durach, C.F.; Wieland, A.; Machuca, J.A.D. Antecedents and dimensions of supply chain robustness: A systematic literature review. Int. J. Phys. Distrib. Logist. Manag. 2015, 45, 118-137. [CrossRef]

198. Gualandris, J.; Kalchschmidt, M. Supply risk management and competitive advantage: A misfit model. Int. J. Logist. Manag. 2015, 26, 459-478. [CrossRef]

199. Gao, L. Collaborative forecasting, inventory hedging and contract coordination in dynamic supply risk management. Eur. J. Oper. Res. 2015, 245, 133-145. [CrossRef]

200. Koronis, E.; Ponis, S.T. Introducing corporate reputation continuity to support organizational resilience against crises. J. Appl. Bus. Res. 2012, 28, 283-290. [CrossRef]

201. Chowdhury, M.; Quaddus, M.; Agarwal, R. Supply chain resilience for performance: Role of relational practices and network complexities. Supply Chain Manag. 2019. [CrossRef]

202. Thomé, A.M.T.; Scavarda, L.F.; Scavarda, A.; Thomé, F.E.S.D.S. Similarities and contrasts of complexity, uncertainty, risks, and resilience in supply chains and temporary multi-organization projects. Int. J. Proj. Manag. 2016, 34, 1328-1346. [CrossRef]

203. Subramanian, N.; Abdulrahman, M. Logistics and cloud computing service providers' cooperation: A resilience perspective. Prod. Plan. Control 2017, 28, 919-928. [CrossRef]

204. Alfaro Saiz, J.J.; Rodriguez, R.; Ortiz Bas, A.; Verdecho, M.J. An information architecture for a performance management framework by collaborating SMEs. Comput. Ind. 2010, 61, 676-685. [CrossRef]

205. Fraile, F.; Tagawa, T.; Poler, R.; Ortiz, A. Trustworthy Industrial IoT Gateways for Interoperability Platforms and Ecosystems. IEEE Internet Things J. 2018, 5, 4506-4514. [CrossRef]

206. Dowty, R.A.; Wallace, W.A. Implications of organizational culture for supply chain disruption and restoration. Int. J. Prod. Econ. 2010, 126, 57-65. [CrossRef]

207. Wedawatta, G.; Ingirige, B.; Amaratunga, D. Building up resilienc e of construction sector SMEs and their supply chains to extreme weather events. Int. J. Strateg. Prop. Manag. 2010, 14, 362-375. [CrossRef]

208. Gabler, C.B.; Richey, R.G., Jr.; Stewart, G.T. Disaster Resilience Through Public-Private Short-Term Collaboration. J. Bus. Logist. 2017, 38, 130-144. [CrossRef]

209. Haraguchi, M.; Lall, U.; Watanabe, K. Building private sector resilience: Directions after the 2015 Sendai framework. J. Disaster Res. 2016, 11, 535-543. [CrossRef]

210. Foster, S.P.; Dye, K. Building continuity into strategy. J. Corp. Real Estate 2005, 7, 105-119. [CrossRef]

211. Gunasekaran, A.; Subramanian, N.; Rahman, S. Supply chain resilience: Role of complexities and strategies. Int. J. Prod. Res. 2015, 53, 6809-6819. [CrossRef]

212. Vargas, J.; González, D. Model to assess supply chain resilience. Int. J. Saf. Secur. Eng. 2016, 6, $282-292$. [CrossRef]

213. Sawyerr, E.; Harrison, C. Developing resilient supply chains: Lessons from high-reliability organisations. Supply Chain Manag. 2020, 25, 77-100. [CrossRef]

214. Ekanayake, E.M.A.C.; Shen, G.Q.P.; Kumaraswamy, M.M. Identifying supply chain capabilities of construction firms in industrialized construction. Prod. Plan. Control 2020. [CrossRef]

215. Yavari, M.; Zaker, H. Designing a resilient-green closed loop supply chain network for perishable products by considering disruption in both supply chain and power networks. Comput. Chem. Eng. 2020, 134, 106680. [CrossRef]

216. Vishnu, C.; Sridharan, R.; Gunasekaran, A.; Ram Kumar, P. Strategic capabilities for managing risks in supply chains: Current state and research futurities. J. Adv. Manag. Res. 2019. [CrossRef]

217. Mandal, S.; Sarathy, R.; Korasiga, V.; Bhattacharya, S.; Dastidar, S. Achieving supply chain resilience: The contribution of logistics and supply chain capabilities. Int. J. Disaster Resil. Built Environ. 2016, 7, 544-562. [CrossRef]

218. Goldbeck, N.; Angeloudis, P.; Ochieng, W. Optimal supply chain resilience with consideration of failure propagation and repair logistics. Transp. Res. Part E Logist. Transp. Rev. 2020, 133. [CrossRef]

219. DuHadway, S.; Carnovale, S.; Hazen, B. Understanding risk management for intentional supply chain disruptions: Risk detection, risk mitigation, and risk recovery. Ann. Oper. Res. 2019, 283, 179-198. [CrossRef]

220. Dutta, P.; Shrivastava, H. The design and planning of an integrated supply chain for perishable products under uncertainties: A case study in milk industry. J. Model. Manag. 2020. [CrossRef] 
221. Mao, X.; Lou, X.; Yuan, C.; Zhou, J. Resilience-based restoration model for supply chain networks. Mathematics 2020, 8, 163. [CrossRef]

222. Saghaei, M.; Ghaderi, H.; Soleimani, H. Design and optimization of biomass electricity supply chain with uncertainty in material quality, availability and market demand. Energy 2020, 197, 117165. [CrossRef]

223. Yan, W.; Cao, H.; Zhang, Y.; Ning, P.; Song, Q.; Yang, J.; Sun, Z. Rethinking Chinese supply resilience of critical metals in lithium-ion batteries. J. Clean. Prod. 2020, 256, 120719. [CrossRef]

224. Tucker, E.L.; Daskin, M.S.; Sweet, B.V.; Hopp, W.J. Incentivizing resilient supply chain design to prevent drug shortages: Policy analysis using two- and multi-stage stochastic programs. IISE Trans. 2020, 52, 394-412. [CrossRef]

225. Adobor, H. Supply chain resilience: A multi-level framework. Int. J. Logist. Res. Appl. 2019, 22, 533-556. [CrossRef]

(C) 2020 by the authors. Licensee MDPI, Basel, Switzerland. This article is an open access article distributed under the terms and conditions of the Creative Commons Attribution (CC BY) license (http://creativecommons.org/licenses/by/4.0/). 